\title{
Kir3 channel signaling complexes: focus on opioid receptor signaling
}

\author{
Karim Nagi ${ }^{1,2}$ and Graciela Pineyro ${ }^{1,2,3}$ * \\ ' Département de Pharmacologie, Faculté de Médecine, Université de Montréal, Montreal, QC, Canada \\ ${ }^{2}$ Centre de Recherche du CHU Sainte-Justine, Montréal, OC, Canada \\ ${ }^{3}$ Département de Psychiatrie, Faculté de Médecine, Université de Montréal, Montréal, QC, Canada
}

\section{Edited by:}

Leigh Anne Swayne, University of

Victoria, Canada

Reviewed by:

Lin Tian, University of California,

Davis, USA

Nathan Dascal, Tel Aviv University,

Israel

\section{*Correspondence:}

Graciela Pineyro, Department of

Psychiatry, Centre de Recherche du

CHU Ste-Justine, University of

Montreal, 3175, Côte Ste-Catherine,

Bureau 2722, Montréal,

OC H3T 1C5, Canada

e-mail: graciela.pineyro.filpo@

umontreal.ca
Opioids are among the most effective drugs to treat severe pain. They produce their analgesic actions by specifically activating opioid receptors located along the pain perception pathway where they inhibit the flow of nociceptive information. This inhibition is partly accomplished by activation of hyperpolarizing $G$ protein-coupled inwardly-rectifying potassium (GIRK or Kir3) channels. Kir3 channels control cellular excitability in the central nervous system and in the heart and, because of their ubiquitous distribution, they mediate the effects of a large range of hormones and neurotransmitters which, upon activation of corresponding G protein-coupled receptors (GPCRs) lead to channel opening. Here we analyze GPCR signaling via these effectors in reference to precoupling and collision models. Existing knowledge on signaling bias is discussed in relation to these models as a means of developing strategies to produce novel opioid analgesics with an improved side effects profile.

Keywords: GIRK, opioid, signaling, analgesia, bias, signaling complexes, functional selectivity, allosteric modulation
Opioids produce their actions via the activation of $\mu$ (MOR), $\delta$ (DOR), and $\kappa$ (KOR) receptors (Pert and Snyder, 1973; Simon et al., 1973) all of which couple to heterotrimeric Gi/o proteins. As such they share adenylyl cyclase, Phospholipase C $\beta$ [PLC $\beta$, $\mathrm{N}$-type $\mathrm{Ca}^{2+}$ (Cav2.2)] channels and G-protein coupled inward rectifier $\mathrm{K}^{+}$channels (GIRKs or Kir3 channels) as canonical $\mathrm{G} \alpha$

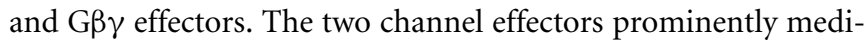
ate analgesic effects of opioids. For example, studies in rodents have shown that activation of MORs on small, unmyelinated nociceptors (Scherrer et al., 2009; Heinke et al., 2011; Bardoni et al., 2014) contribute to the analgesic effects of morphine (Wei et al., 1996; Andrade et al., 2010), and this is done via inhibition of N-type $\mathrm{Ca}+2$ channels that control neurotransmitter release from these primary afferents (Glaum et al., 1994; Wrigley et al., 2010). Kir3 channel contribution to opioid analgesia has also been demonstrated in animal models (Ikeda et al., 2000; Mitrovic et al., 2003; Marker et al., 2005), and their relevance in the clinical response to opioid analgesics has been further confirmed by

\footnotetext{
Abbreviations: GIRK, G protein activated inward rectifier $\mathrm{K}^{+}$; GPCRs, $\mathrm{G}$ protein-coupled receptors; DORs, Delta opioid receptors; MORs, Mu opioid receptors; KORs, Kappa opioid receptors; PLC, Phospholipase C; GABA, Gamma-aminobutyric acid; DRG, dorsal root ganglion; DAMGO, [D-Ala(2),NMe-Phe(4),Gly(5)-ol]-enkephalin; KCNJ6, Inwardly-rectifying potassium channel, subfamily J, member 6; KCNJ3, Inwardly-rectifying potassium channel, subfamily J, member 3; 5-HT, 5-hydroxytryptamine; MAPK, Mitogen-activated protein kinases; $\beta$ arr, $\beta$ arrestin; cAMP, Cyclic adenosine monophosphate; VTA, Ventral tegmental area; PIP2, Phosphatidylinositol 4,5-bisphosphate; GDP, Guanosine diphosphate; GTP, Guanosine triphosphate; PSD95, Postsynaptic density protein 95; SAP97, Synapse-associated protein 97; FRET, Fluorescence resonance energy transfer; BRET, Bioluminescence resonance energy transfer; PC12, Neuron-like pheochromocytoma.
}

gene linkage analyses (Nishizawa et al., 2009; Lotsch et al., 2010; Bruehl et al., 2013). In addition, the use of genetically modified mice lacking different channel subunits has further established activation of Kir3 channels as a pervasive analgesic mechanism which, in addition to opioids, also mediates pain modulation by $\alpha 2$ adrenergic, muscarinic, $G_{A B A}$ and cannabinoid receptor ligands (Blednov et al., 2003; Mitrovic et al., 2003). From this perspective the development of direct Kir3 channel activators may be considered a promising strategy for the development of novel analgesics. However, enthusiasm for this particular approach has remained limited given the possibility of widespread side-effects associated with administration of direct channel openers (Lujan et al., 2014). Indeed, these would result from the great variety of physiological responses mediated by Kir3 channels, including heart frequency control (Wickman et al., 1998; Bettahi et al., 2002), memory (Wickman et al., 2000), learning (Wickman et al., 2000; Cooper et al., 2012), as well as their participation in different pathological conditions including development of seizures (Signorini et al., 1997), generation of anxiety states (Blednov et al., 2001; Pravetoni and Wickman, 2008) and contribution to abnormal plasticity by drugs of abuse (Padgett et al., 2012; Hearing et al., 2013). Consequently, the prevailing strategy for engaging Kir3-mediated analgesia has remained the activation of pain-modulating GPCRs (McAllister et al., 1999; Lujan et al., 2014). Among them MORs, DORs and KORs all three mediate effective analgesia but display different side effects that distinctively limit their therapeutic use (Kieffer and Gaveriaux-Ruff, 2002; Bruchas and Chavkin, 2010; Gaveriaux-Ruff and Kieffer, 2011). Here we will summarize Kir3 channel contribution to desired and undesired responses of opioid analgesics and address 
the question of whether biasing opioid signaling toward these effectors could help develop better opioid analgesics with a reduced side effects profile.

\section{Kir3 CHANNEL SIGNALING AND OPIOID-DEPENDENT ANALGESIA}

Kir3 channels are formed by tetrameric association of four different subunits (Kir3.1-3.4). Although all four of them are expressed in peripheral (Gao et al., 2007) and central nervous system (Wickman et al., 2000; Saenz Del Burgo et al., 2008; FernandezAlacid et al., 2011), neural channels are most frequently formed by association of Kir3.1, 3.2 and 3.3 subunits (Liao et al., 1996; Hibino et al., 2010; Luscher and Slesinger, 2010). The subunit combination that forms the channel will depend on the neuronal population involved (Inanobe et al., 1999; Cruz et al., 2004) and the cellular compartment (Koyrakh et al., 2005; FernandezAlacid et al., 2009) in which channels are found. Nonetheless, Kir3.1/3.2 heterotetramers are considered prototypical neuronal channels.

Kir3 channel contribution to opioid analgesia was initially suggested by the fact that mice carrying a missense mutation which renders Kir3.2 subunits insensitive to G protein activation (Patil et al., 1995; Navarro et al., 1996) displayed reduced analgesic responses to morphine (Ikeda et al., 2000, 2002). These observations were subsequently confirmed using null mice for different subunits (Mitrovic et al., 2003; Marker et al., 2005), which allowed to also implicate Kir3.1 (Marker et al., 2004) and Kir3.3 (Marker et al., 2002) in pain modulation. Knock-out of Kir3.2 and 3.3 was shown to interfere with morphine's ability to prolong avoidance behavior in the hot plate test. Since this response involves supraspinal integration, it can be concluded that both subunits contribute to mechanisms of opioid analgesia at this level (Marker et al., 2002; Mitrovic et al., 2003). Possible sites of supraspinal Kir3-mediated analgesia may include thalamus and limbic cortex, both of which express Kir3.1, 3.2 and 3.3 subunits (Saenz Del Burgo et al., 2008; Fernandez-Alacid et al., 2011) as well as opioid receptors (Le Merrer et al., 2009). The midbrain periaqueductal gray seems less likely since in this nucleus opioid actions are primarily presynaptic reducing neurotransmitter release via a mechanism that involves phospholipase A2, arachidonic acid and 12-lipoxygenase, which leads to modulation of voltage-dependent potassium channels (Vaughan and Christie, 1997; Vaughan et al., 1997).

Genetically engineered mice lacking Kir3.1 or Ki3.2 subunits also display reduced responses to intrathecal administration of morphine in the tail flick test (Marker et al., 2004, 2005) implicating both subunits in spinal mechanisms of opioid analgesia. This interpretation is supported by reports locating Kir3.1 and Kir3.2 subunits to lamina II interneurons that co-express $\mu$ opioid receptors (Marker et al., 2006). Functional studies also indicated that silencing of Kir3.1 or Kir3.2 subunits, or intrathecal infusion of Kir3 channel blocker tertiapin-Q interfered with the analgesic response by MOR and DOR agonists administered by the same route (Marker et al., 2005). In contrast, Kir3.3 ablation was without effect on the analgesic response elicited by intrathecal morphine (Marker et al., 2004), arguing against its significant contribution at this level. The latter observation is also in keeping with immunohistological studies which reported absence of Kir3.3 labeling in the dorsal horn (Marker et al., 2004).

In addition to their participation in acute opioid analgesia, spinal Kir3 channels seem to mediate neuroadaptations that modulate responsiveness to opioids in conditions such as inflammatory or cancer-related pain. This possibility is particularly suggested by reports indicating that carrageenan-inflammation (Gonzalez-Rodriguez et al., 2010) and bone cancer (GonzalezRodriguez et al., 2012) enhance the inhibitory effect of Kir3 channel blocker tertiapin-Q on analgesia induced by intrathecal administration of morphine.

Apart from brain and spinal cord, opioid receptors are also present in sensory neurons of the dorsal root ganglion (DRG) (Li et al., 1998; Gendron et al., 2006; Wu et al., 2008; Wang et al., 2010) and are transported to peripheral terminals where they mediate analgesic actions of peripherally injected opioids (Hassan et al., 1993; Obara et al., 2009; Vadivelu et al., 2011). Transcripts for Kir3.1/3.2 subunits have been detected in human DRGs and in rat nociceptors, but not in mice (Gao et al., 2007; Nockemann et al., 2013). This distribution parallels differences in species sensitivity to peripheral administration of opioids suggesting that when expressed, DRG Kir3 subunits actively participate in opioid analgesia. Indeed, intraplantar injection of MOR agonists does not produce analgesia in mice (Nockemann et al., 2013) but effectively mitigates pain in inflammatory or neuropathic rat models (Stein et al., 1989; Obara et al., 2009; Chung et al., 2013; Nockemann et al., 2013) as well as postoperative and arthritic pain in humans (Kalso et al., 2004; Vadivelu et al., 2011). Moreover, the active contribution of Kir3.2 channels to peripheral opioid analgesia has now been experimentally established using transgenic mice genetically engineered to express these subunits in sensory neurons. Unlike their wild-type counterparts, the latter display an analgesic response to plantar application of MOR agonist DAMGO (Nockemann et al., 2013).

It is important to bear in mind that most of the evidence analyzed thus far links Kir3 channel function to opioid analgesia in animal models. However, the latter have shown somewhat limited success in identifying and validating analgesic targets of clinical relevance (Mogil, 2009). Hence, from this perspective, any evidence linking Kir3 channels to therapeutic response in humans is of specific interest. At least three studies have now shown that variations in the gene coding for Kir3.2 subunits (KCNJ6) influence opioid dose requirements for both acute management of postoperative pain (Nishizawa et al., 2009; Bruehl et al., 2013) and for pain control in chronic patients (Lotsch et al., 2010). Similar assessment of Kir3.1 (KCNJ3) variations showed no effect (Bruehl et al., 2013).

\section{OPIOID SIDE EFFECTS AND Kir3 CHANNEL SIGNALING}

In spite of the established analgesic efficacy of MOR, DOR, and KOR agonists, activation of the different receptor subtypes results in a distinct set of side effects which limit therapeutic application of their agonists. Constipation, nausea, respiratory depression, tolerance, dependence, and abuse are among the most common undesired effects of clinically available MOR agonists (Ballantyne and Shin, 2008; Morgan and Christie, 2011). Many of these undesired actions, particularly respiratory depression (Cheng et al., 
1993; Gallantine and Meert, 2005), gastrointestinal side effects (Tavani et al., 1990; Gallantine and Meert, 2005; Feng et al., 2006) and physical dependence (Cowan et al., 1988; Codd et al., 2009) are less severe or absent with DOR agonists. Moreover, although DORs and MORs are both involved in reward response to physiological stimuli (Charbogne et al., 2014), DORs are not directly involved in assigning reward value to stimuli but instead facilitate predictive learning and influence the choice of action in face of contingencies that involve reward (Laurent et al., 2012). In keeping with this functional profile, DOR agonists do not facilitate intracranial self-stimulation (Do Carmo et al., 2009), are not discriminated as morphine substitutes (Gallantine and Meert, 2005) and do not display reinforcing properties in non-human primates (Banks et al., 2011). Nonetheless, despite these advantages, potential for tolerance (Pradhan et al., 2010; Audet et al., 2012) remains a limitation for long-term use of DOR agonists, as does their propensity to produce hippocampal hyperexcitability that may lead to seizures. The latter are produced both by DOR (De Sarro et al., 1992; Broom et al., 2002; Jutkiewicz et al., 2005) and MOR agonists (Drake et al., 2007). In the specific case of DOR agonists, hyperexcitability is brief and non-lethal. Moreover, seizures are rare at analgesic doses (Jutkiewicz et al., 2006), they do not appear with all ligands (Le Bourdonnec et al., 2008; Saitoh et al., 2011) and can be suppressed by controlling the rate of agonist administration (Jutkiewicz et al., 2005). Thus, overall, side effects of DORs agonists are considerably milder as compared to those of MORs, and their proven efficacy in chronic pain management make DORs especially attractive as targets for the development of novel analgesics (Gaveriaux-Ruff and Kieffer, 2011). This notion is further reinforced by the fact that DOR agonists display antidepressant properties (Chu Sin Chung and Kieffer, 2013) which could be of additional benefit in controlling negative affect, frequently associated with prolonged pain syndromes (Goldenberg, 2010). Unlike DOR agonists, KOR-mediated analgesia is typically associated with stress, depression, and dysphoria (Bruchas and Chavkin, 2010; Van't Veer and Carlezon, 2013) which, together with their tendency to induce tolerance (McLaughlin et al., 2004; $\mathrm{Xu}$ et al., 2004), would make these ligands less attractive for the treatment of chronic pain.

Kir3 channel function has been associated with some of the undesired effects of opioid analgesics. For example, reduced GABAergic activity in hippocampal dentate gyrus increases the excitability of glutamatergic granule cells and may reduce the threshold for seizures (Drake et al., 2007). MORs and DORs agonists silence hippocampal GABAergic interneurons by a mechanism that involves both Kir3 (Luscher et al., 1997) and voltage-dependent $\mathrm{K}^{+}$channels (Wimpey and Chavkin, 1991; Moore et al., 1994), explaining their documented tendency to produce seizures (Drake et al., 2007). MORs agonists also enhance excitability and firing activity of dopaminergic neurons of the ventral tegmental area (Gysling and Wang, 1983), and do so by hyperpolarization of local interneurons (Johnson and North, 1992; Bonci and Williams, 1997). Like in hippocampus, disinhibition is mediated through Kir3 channel activation (Luscher et al., 1997) and its consequence is the enhanced release of dopamine in corticolimbic areas which is thought to facilitate compulsive behaviors characteristic of addiction (Luscher and Ungless, 2006).
Finally, Kir3 channel activation by KORs modulates firing activity of dorsal raphe 5-HT neurons (Bruchas et al., 2007; Lemos et al., 2012). Dynorphin release during repeated stress exposure produces sustained activation of these receptors driving p38 $\alpha$ MAPK activity and subsequent Kir3.1 subunit phosphorylation (Lemos et al., 2012). As a consequence 5-HT neuron firing activity becomes deregulated, possibly contributing to dysphoric effects of uncontrollable stress and to aversive actions of KOR agonists (Bruchas et al., 2007).

Additional undesired actions of opioids analgesics involve signaling effectors other than Kir3 channels. For example, constipation and respiratory depression have been associated with $\beta$ arrestin ( $\beta$ arr)-mediated signaling by MOR agonists (Raehal et al., 2005; Dewire et al., 2013). The use of $\beta$ arr-knockout mice has also suggested that DOR agonist tendency to induce seizures may involve this regulatory protein, and biased agonists that fail to recruit $\beta$ arrs are being developed as a means of further improving the side effects profile of analgesics acting at this receptor subtype. Kir3-independent side effects also include compensatory changes in the cyclase pathway (cyclase superactivation). These are triggered by sustained inhibition of cAMP production (Christie, 2008) and have been shown to contribute to physical dependence (Han et al., 2006; Cao et al., 2010; Yang et al., 2014) and analgesic tolerance of opioid agonists (Javed et al., 2004; He and Whistler, 2007; Bobeck et al., 2014).

Data summarized thus far indicate that undesired actions of opioid ligands segregate according to receptor subtype, and within each subtype, desired and unwanted effects are not all necessarily mediated by the same effectors. Thus, undesired actions of DOR and KOR-activating analgesics are less than those of MOR ligands, and among the former, the presence of antidepressant properties and lack of dysphoric actions makes DOR specifically interesting as putative targets for the management of chronic pain syndromes (Gaveriaux-Ruff and Kieffer, 2011; Pradhan et al., 2011). Tolerance however, remains a drawback that limits further development of DOR-acting analgesics. This limitation could be, at least, partly addressed by taking advantage of biased signaling since effectors that mediate cellular tolerance and analgesia seem partly segregated. Indeed, as detailed above, while analgesic actions are generally mediated via modulation of channel effectors, adaptations of the cAMP cascade seem to account for at least some of the manifestations of tolerance (Javed et al., 2004; He and Whistler, 2007; Bobeck et al., 2014). Based on these observations, opioid ligands that specifically bias their pharmacological stimulus toward channel effectors could conceivably conserve analgesic properties while displaying reduced potential for tolerance, particularly the component that depends on cyclase adaptations. In the following sections, we will consider possible strategies to direct opioid signaling toward Kir3 channels. However, before doing so it is worth revising the events that lead to channel activation.

\section{Kir3 CHANNEL ACTIVATION VIA GPCRS}

It is now well established that Kir3 channels open via direct interaction with $G \beta \gamma$ dimers that are released from pertussis toxin sensitive heterotrimeric Gi/o proteins upon receptor activation (Logothetis et al., 1987; Wickman et al., 1994; Raveh 
et al., 2009). G $\beta \gamma$ activates the channel as long as the surface that contacts Kir3 subunits does not re-associate with $\mathrm{G} \alpha_{\mathrm{i} / \mathrm{o}}-\mathrm{GDP}$, which results in signal termination (Schreibmayer et al., 1996). Biochemical, mutational and nuclear magnetic resonance studies have mapped several interaction sites for G $\beta \gamma$ on all four channel subunits. These sites are summarized in Table 1 and those in the C-terminal cytosolic domain have been largely confirmed in recent crystallization of a complex formed by $G \beta 1 \gamma 2$ and the Kir3.2 homotetramer (Whorton and MacKinnon, 2013). Crystals of the complex revealed that the contact area between $\mathrm{G} \beta$ and the channel is approximately $700 \mathrm{~A}^{\circ 2}$. The contact zone on channel subunits corresponds to the interface of two contiguous cytosolic domains encompassing $\beta$ sheets/loops $\beta \mathrm{K}, \beta \mathrm{L}, \beta \mathrm{M}$, and $\beta \mathrm{N}$ on one subunit and $\beta \mathrm{D}-\beta \mathrm{E}$ elements from the adjacent one. The

Table 1 | G $\beta \gamma$ interaction sites on different Kir3 subunits.

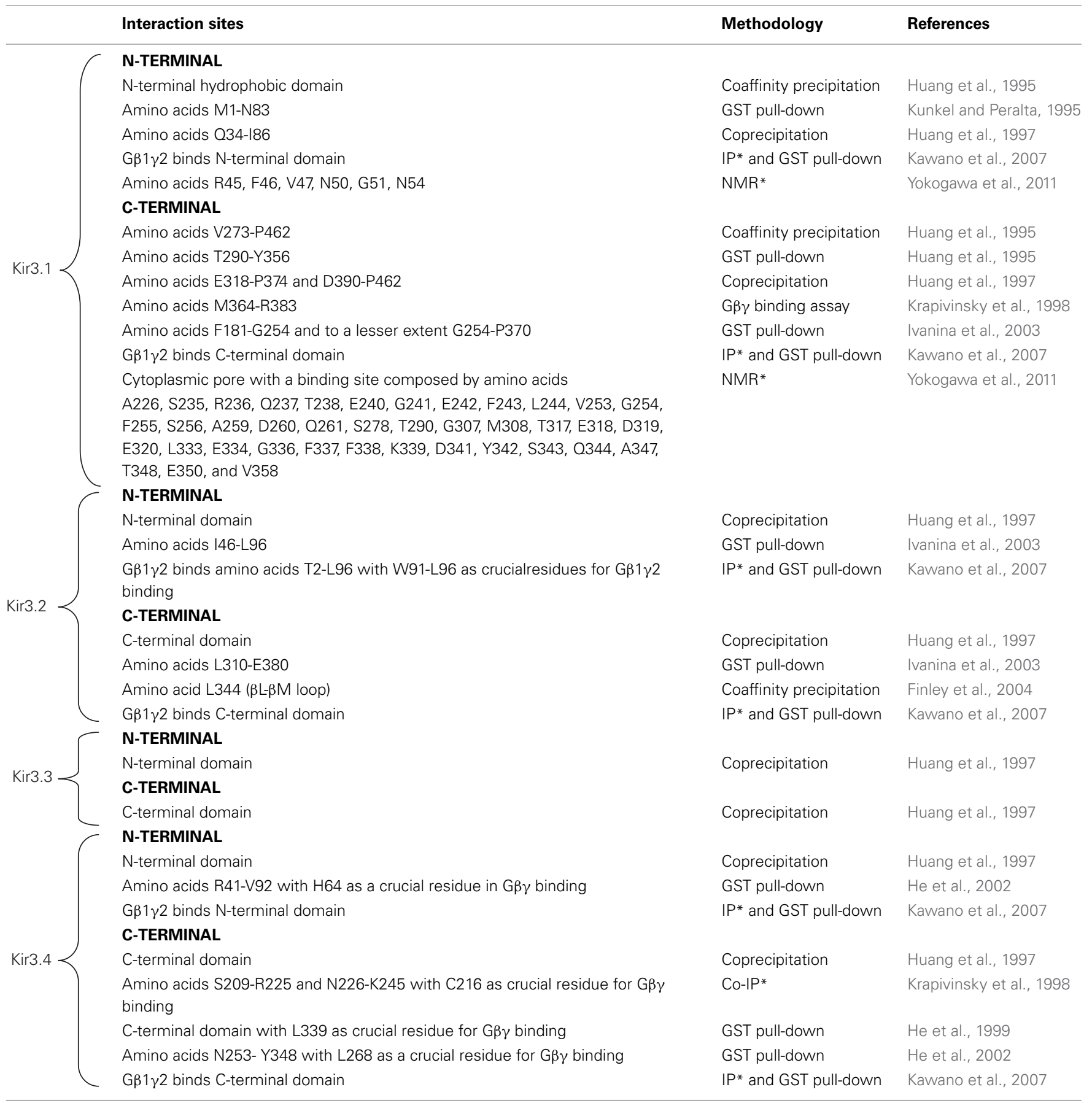

IP, Immunoprecipitation; NMR, Nuclear magnetic resonance spectroscopy. 
channel's interaction surface on $\mathrm{G} \beta$ overlaps the $\mathrm{G} \alpha$ binding site (Ford et al., 1998; Whorton and MacKinnon, 2013). The arrangement of Kir3.2 and G $\beta \gamma$ subunits within the crystal corresponds to a membrane-delimited signaling complex consisting of one channel tetramer, four $\mathrm{G} \beta \gamma$ subunits, four phosphatidylinositol 4,5-bisphosphate $\left(\mathrm{PIP}_{2}\right)$ molecules and four $\mathrm{Na}^{+}$ions bound to corresponding regulatory sites on the channel (Whorton and MacKinnon, 2011). This organization is compatible with $\mathrm{G} \beta \gamma$ binding to the channel to induce an intermediate active state that is stabilized into the full open conformation by $\mathrm{PIP}_{2}$ and $\mathrm{Na}^{+}$ ions (Whorton and MacKinnon, 2011, 2013). Interaction sites for $\mathrm{G} \alpha_{\mathrm{i} / \mathrm{o}}$ have also been mapped to all four channel subunits, both in GDP- and GTP-bound states and these sites as summarized in Table 2 .

Although structural determinants of channel activation are matter of considerable consensus, the dynamics that govern the process remain subject of active investigation. Originally, GPCRs, $G$ proteins and channels were conceived as isolated membrane entities capable of conveying pharmacological stimuli from receptors to effectors through a series of collisions which included the $G$ protein as intermediary (Orly and Schramm, 1976; Tolkovsky and Levitzki, 1978). However, the perception that this original formulation of the collision coupling model failed to account for the specificity and temporal resolution of Kir3 channel signaling has led to the proposal of alternative paradigms (Neubig, 1994). One of such alternatives postulates that receptors and their signaling partners may be precoupled in the absence of agonist (Wreggett and De Lean, 1984; Tian et al., 1994) while another proposes that receptors, their $\mathrm{G}$ proteins and effectors are compartmentalized within microdomains (Neubig, 1994; Neer, 1995) where signaling partners are present in high enough concentrations to allow rapid interactions by collision (Gross and Lohse, 1991). In the case of neurons, postsynaptic densities are typically specialized domains where anchoring and scaffolding proteins control signaling partners present within dendritic spines (Romero et al., 2011; Fourie et al., 2014). Kir3.2c subunits directly interact with post synaptic density protein 95 (PSD95) and synapse-associated protein 97 (SAP97), two such proteins which not only regulate local concentration of channel subunits but their responsiveness to $G$ proteins as well (Inanobe et al., 1999; Hibino et al., 2000; Nassirpour et al., 2010).

The idea that receptors and channels may associate to form a complex is supported by evidence obtained in native and heterologous systems. Thus, in co-immunoprecipitations from brain samples Kir3 subunits can be recovered with dopamine $\mathrm{D}_{2}$ (Lavine et al., 2002) or $\mathrm{GABA}_{\mathrm{B}}$ receptors (Ciruela et al., 2010). Functional evidence is also consistent with the notion that native receptors and channels may associate. For example, immobilization of MORs receptors expressed in cerebellar granule cells does not alter the rate of Kir3 channel activation, implying

Table 2 | $\mathbf{G} \alpha$ interaction sites on different Kir3 subunits.

\begin{tabular}{|c|c|c|c|}
\hline & Interaction sites & Methodology & References \\
\hline \multirow{10}{*}{ Kir3.1 } & N-TERMINAL & & \\
\hline & G $\alpha$-GDP binds N-terminal domain & Coaffinity precipitation & Huang et al., 1995 \\
\hline & Gai1-GDP binds N-terminal domain & GST pull-down & Ivanina et al., 2004 \\
\hline & Gaq-GDP binds N-terminal domain & $\mathrm{IP}^{*}$ and GST pull-down & Kawano et al., 2007 \\
\hline & Gai3-GDP and Gai3-GTP bind N-terminal domain & GST pull-down & Berlin et al., 2010 \\
\hline & C-TERMINAL & & \\
\hline & Gai3-GDP binds amino acids F181-G254, G254-D319, and E320-P370 & GST pull-down & Ivanina et al., 2004 \\
\hline & Gai1-GDP binds amino acids G254-D319 & & \\
\hline & Gai3-GDP and Gai3-GTP bind amino acids M184-E362 & GST pull-down & Berlin et al., 2010 \\
\hline & $\begin{array}{l}\text { Gai3-GTP binds amino acids E242, V358, L365, L366, M367, S368, S369, L371, } \\
\text { I372, and A373 }\end{array}$ & $\mathrm{NMR}^{*}$ & Mase et al., 2012 \\
\hline \multirow{8}{*}{ Kir3.2 } & N-TERMINAL & & \\
\hline & Gai3-GDP binds amino acids I46-L96 & GST pull-down & Ivanina et al., 2004 \\
\hline & G $\alpha$ o-GDP and G $\alpha q-G D P$ bind to N-terminal domain & Co-IP* and GST pull-down & Clancy et al., 2005 \\
\hline & $\begin{array}{l}\text { G } \alpha \text { q-GDP binds amino acids T51-K90 with D81-K90 as crucial residues for } \\
\text { G } \alpha \text { q-GDP binding }\end{array}$ & $\mathrm{IP}^{*}$ and GST pull-down & Kawano et al., 2007 \\
\hline & C-TERMINAL & & \\
\hline & Gai3-GDP binds amino acids L310-E380 & GST pull-down & Ivanina et al., 2004 \\
\hline & Gai1-GDP binds amino acids M191-G414 & GST pull-down & Clancy et al., 2005 \\
\hline & $\begin{array}{l}\text { G } \alpha \text { o-GDP binds amino acids E314-S330 with G318, C321, A323, I328, T329, and } \\
\text { S330 as critical residues for Gao-GDP binding }\end{array}$ & & \\
\hline \multirow{4}{*}{ Kir3.4 } & N-TERMINAL & & \\
\hline & Gaq-GDP binds N-terminal domain & IP* and GST pull-down & Kawano et al., 2007 \\
\hline & C-TERMINAL & & \\
\hline & Gai-GDP and Gaq-GDP bind C-terminal domain & GST pull-down & Rusinova et al., 2007 \\
\hline
\end{tabular}

IP, Immunoprecipitation; NMR, Nuclear magnetic resonance spectroscopy. 
that neither species freely diffuses within the membrane during signaling (Lober et al., 2006). More at a systems level, neuroadaptive changes induced by psychostimulants also suggests physical association between receptors and Kir3 channels. In particular, heterologous regulation of $\mathrm{GABA}_{\mathrm{B}}$ receptors causes them to cointernalize with Kir3 subunits in the ventral tegmental area (VTA) (Padgett et al., 2012) and in pyramidal neurons of the prelimbic cortex (Hearing et al., 2013) following administration of cocaine or amphetamines. Similar conclusions were drawn from studying receptor trafficking in PC12 neurons where homologous desensitization of native muscarinic M2 receptors drives internalization and intracellular accumulation of Kir3 subunits (Clancy et al., 2007). However, a limitation with this group of observations is that native systems not always allow to rule out receptor activation by endogenous ligands, making it difficult to ascertain whether signaling complexes are spontaneously formed or if they result from receptor activation.

Spectroscopic studies in overexpression systems have proven valuable in assessing spontaneous interactions and in providing detailed kinetics of the steps involved in Kir3 activation. In heterologous systems, fluorescence resonance energy transfer (FRET) and bioluminescence resonance energy transfer (BRET)based approaches have both revealed spontaneous energy transfer between channel subunits and G proteins (Riven et al., 2006; Robitaille et al., 2009; Berlin et al., 2010, 2011) and between the latter and receptors (Rebois et al., 2006; Audet et al., 2008). For opioid receptors in particular, DORs were shown to organize into multimeric arrays that also contain G $\alpha \circ A \beta 1 \gamma 2$ and Kir3.1/Kir3.2 subunits (Richard-Lalonde et al., 2013). However, some of these constitutive associations have not been consistently observed. For example, BRET studies show that $\alpha 2 \mathrm{~A}$-adrenergic receptors precouple to Gail (Gales et al., 2006) but FRET data indicate that

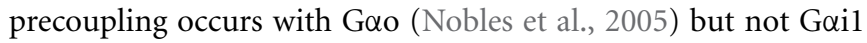
(Hein et al., 2005). These discrepancies have been explained by different arguments: (a) differences in sensitivity between the two techniques would allow BRET to detect lower basal levels of interaction than FRET; (b) receptors do not display the same affinity for different $\mathrm{G} \alpha$ subunits, and (c) receptors with different levels of constitutive activity have different levels of $G$ protein precoupling as reviewed in Lohse et al. (2012).

Kinetic approaches have also addressed the question of whether receptors and $G$ protein precouple in the absence of ligand. For example, FRET assays have established that the time course of conformational changes undergone by the receptor's third intracellular loop upon its activation $(50 \mathrm{~ms}-1 \mathrm{~s})$ (Vilardaga et al., 2003) may be undistinguishable from the kinetics of receptor conformational rearrangements with respect to the $G$ protein (Hein et al., 2005; Jensen et al., 2009). Although these findings argue in favor of precoupling, other observations can be taken as evidence of collision, particularly the fact that the speed of FRET changes that were observed at the interface of the receptor with the $G$ protein varies with the concentration of agonist used to activate the receptor (Hein et al., 2005) and with the amount of G proteins expressed (Hein et al., 2005; Falkenburger et al., 2010). Indeed, both findings are consistent with the essence of the collision model, namely that activated receptors have free access to a common pool of G-proteins. Nonetheless these observations can also be accommodated by a precoupling model if one conceives receptor signaling in terms of conformational ensembles (Kenakin and Onaran, 2002). According to the latter model, a FRET value can be considered representative of a macroscopic state which arises from an ensemble of different receptor states. Within this context, FRET changes corresponding to "receptor activation" represent a multiplicity of states undergoing some degree of conformational change which involves the displacement of the third intracellular loop, not all of which necessarily achieve the full conformational alteration that leads to $G$ protein activation. As agonist concentrations increase and more receptors become permanently occupied by the ligand, the ensemble is progressively constrained so that all states achieve the conformational change that effectively modifies energy transfer between receptors and downstream signaling partners. The increased efficiency, with which higher concentrations of agonist allow the ensemble to attain conformational changes that fully modify the receptor $\mathrm{G}$ protein interface, may translate as an increase in the speed with which the two signaling partners reach maximal FRET. This enhanced efficiency to attain full activation may take place in a receptor ensemble that is precoupled to the $G$ protein. Converse reasoning may be applied to explain how an increase in G protein concentrations may enhance the speed of FRET changes at its interface with the receptor in the context of a precoupling model. Indeed, when $\mathrm{G}$ proteins are a limiting factor, some receptors are precoupled and others not. As recently demonstrated in crystallographic studies, agonist-occupied receptors will not become fully activated unless coupled to a G protein (Rasmussen et al., 2011). In such case enhanced precoupling that takes place upon higher availability of the $G$ protein will increase the probability of the receptor ensemble of achieving a full active state which evokes an effective conformational rearrangement vis a vis the $G$ protein. As above, the ensemble's improved efficiency to achieve this activation state can be perceived as an increase in the speed with which energy is transferred between activated receptors and $G$ proteins.

FRET technology has also been used in combination with total internal reflection to demonstrate that $G$ protein subunits and Kir3 channels may organize into a membrane-delimited preformed complex (Riven et al., 2006). Constitutive association between Kir3 and G $\beta \gamma$ subunits has also been observed by means of BRET (Rebois et al., 2006; Robitaille et al., 2009; RichardLalonde et al., 2013). Moreover, the fact that kinetics of Kir3 channel currents are concordant with conformational changes undergone within the $\mathrm{G} \alpha \beta \gamma$ trimer upon activation (Bunemann et al., 2003), has been taken as an additional argument favoring pre-association between $\mathrm{G}$ proteins and channel effectors (Lohse et al., 2012).

An aspect upon which BRET and FRET data consistently agree, is the fact that $G$ proteins remain associated with the receptor at least during initial stages of signaling (Gales et al., 2005, 2006; Hein et al., 2005, 2006) implying that at one point in time the receptor, the $\mathrm{G}$ protein and the effector are all part of the same complex. This reasoning is also in line with evidence summarized in the previous paragraph, which would place the transducer in direct contact with the effector even before activation. This kind of "triple multimeric array" has been described for DORs, G $\alpha \mathrm{oA} \beta 1 \gamma 2$ and Kir3.1/Kir3.2 subunits using BRET 
A

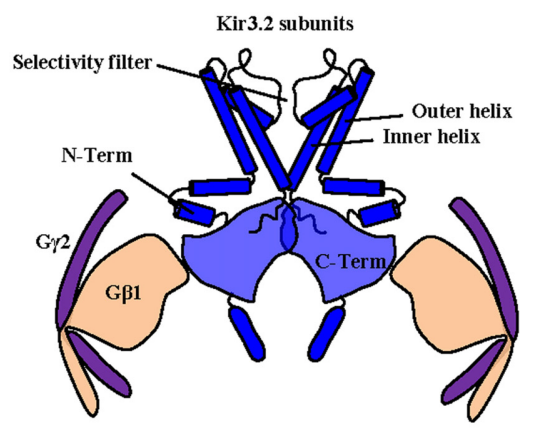

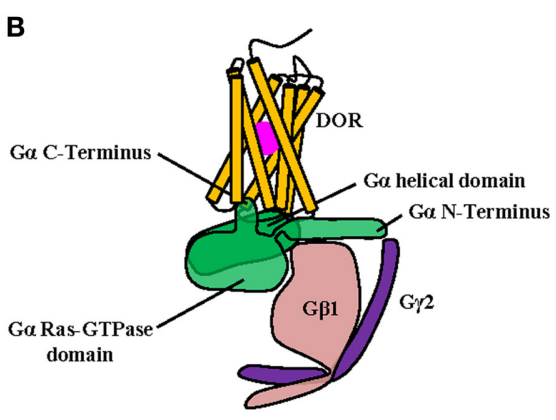

C
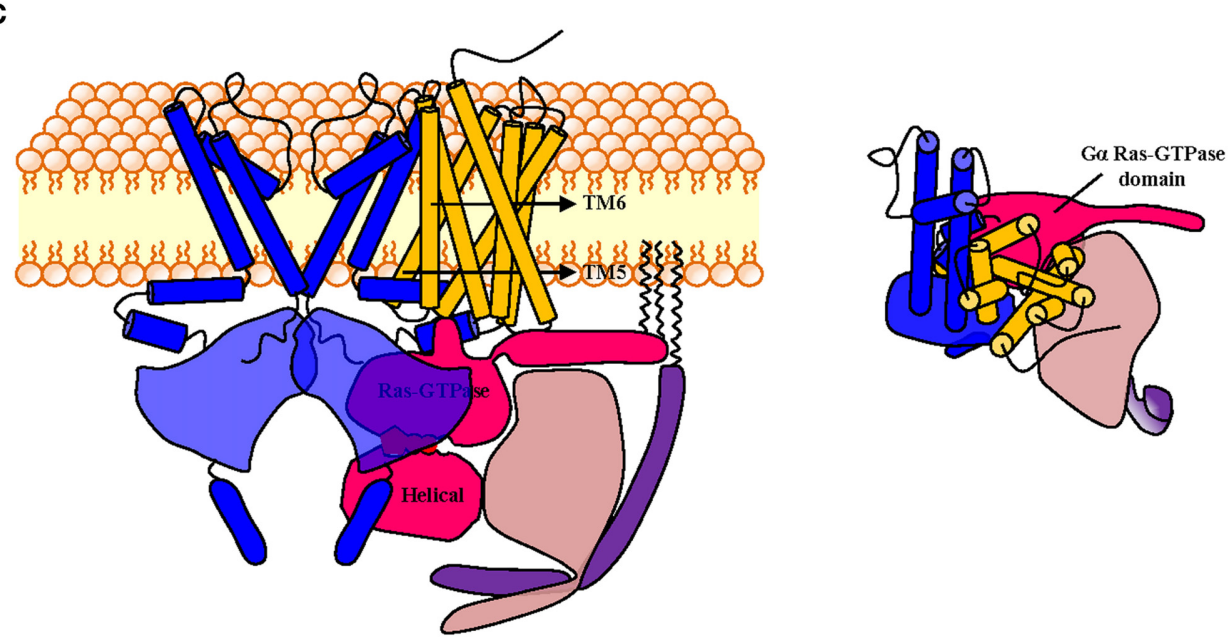

D
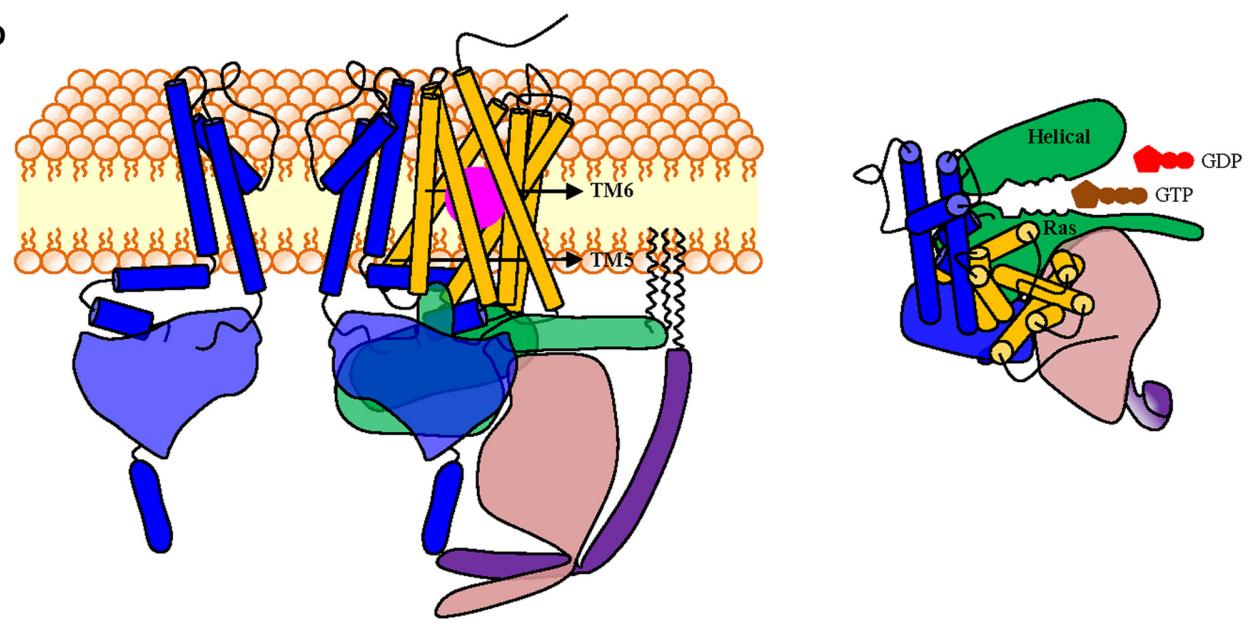

FIGURE 1 | Schematic representation of putative spatial organization of DORs, Kir3.2 and the $\mathrm{G} \alpha \beta \gamma$ subunits within a signaling complex containing all signaling partners. The complex was constructed from diagrams based on the published crystal structures of the Kir3.2 tetramer in association with corresponding G $\beta 1 \gamma 2$ subunits (PDB: 4KFM) (A) and that of the nucleotide-free $\mathrm{G} \alpha \mathrm{s} \beta 1 \gamma 2$ trimer in association with the active $\beta 2$ adrenergic receptor (PDB: $3 s n 6$ ) where the latter was replaced by the topography corresponding to the DOR crystal (PDB: 4EJ4). Note that in the active receptor-G protein complex only the Ras-GTPase domain of $G \alpha$ is fully visible (B). To construct the multimeric array, the DOR-G $\alpha \beta \gamma$ complex shown in $B$ was associated to the Kir3.2 channel shown in (A) by superimposing both $G \beta \gamma$ dimers and then removing the one corresponding to the channel. DOR and Kir3.2 subunits were both aligned with respect to the plain of the membrane. By completing this operation transmembrane domains 5 and 6 of the receptor came in close proximity of the outer helix of the channel subunit. The complex is shown in its inactive state where the helical and GTPase domains of $\mathrm{G} \alpha$ are visible and in contact with $\mathrm{G} \beta \gamma$. The inset shows topography of a single channel subunit with its corresponding $\mathrm{G} \alpha \beta \gamma$ heterotrimer and DOR seen from above (C). In the active complex the agonist (violet) is bound to the receptor, the third intracellular loop is displaced toward the channel, the $\mathrm{C}$-terminal end of $\mathrm{G} \alpha$ insinuates between intracellular loops 2 and 3 . For the proposed multimeric organization to be functional the complex must allow the displacement of the helical domain of $\mathrm{G} \alpha$ upon nucleotide exchange; this is indeed the case since its helical domain moves laterally, from its initial position in the lower part of the inactive complex. Inset shows topography from above (D). 
assays and co-immunoprecipitation in overexpression systems. Moreover, BRET changes that were observed among different interaction partners revealed that the conformational information that is codified by agonist binding to the receptor is relayed to the channel via the G protein (Richard-Lalonde et al., 2013). Figure 1 shows a schematic representation of how DORs, Kir3.2 and $G \alpha \beta \gamma$ subunits could organize within a multimeric array with the receptor in its inactive (Figure 1C) or its active (Figure 1D) states. The proposed complex is based on published structures for the G $\beta \gamma$-bound semi-open Kir3.2 channel (1A) (Whorton and MacKinnon, 2013) and an activated receptor-G protein complex (1B) (Rasmussen et al., 2011). In this putative array receptor and channel were allowed to maintain their positioning with respect to the plain of the membrane while receptor and $G$ protein maintained their relative orientation with respect to one another, as described for the crystallized receptor-G protein complex (Rasmussen et al., 2011). Interestingly, if the diagram had been produced maintaining G $\beta \gamma$ 's inclination with respect to the channel (Whorton and MacKinnon, 2013), the latter would have collided with the receptor. This suggest that, in order to organize into a complex, the different signaling partners most likely influence their mutual positions. If each of the four G $\beta \gamma$ subunits, that associate to Kir3.2 subunits in the crystal, interacts with one Gai/o, and these in turn couple to a corresponding GPCR, it is conceivable that one receptor- $G$ protein complex could occupy one of the grooves that correspond to the site of interaction between two adjacent Kir3 subunits (Figures 1C,D). A supramolecular organization which involves simultaneous association of all signaling partners is compatible with the notion that ligand-specific conformational changes undergone by the receptor can translate into ligand-specific patterns of channel activation. Moreover, allosteric interactions within the array could allow a precoupling model to explain additional observations that are usually attributed to a collision model. For example, the fact that it is possible to attain maximal Kir3 channel currents at concentrations that produce submaximal conformational rearrangement of receptor-G protein interface (Hein et al., 2005) can be explained by positive cooperativity among channel subunits and with the activated G $\beta \gamma$ dimers, even if not all receptors have been occupied and undergone conformational changes associated with activation.

\section{IS IT POSSIBLE TO BIAS PHARMACOLOGICAL STIMULI TOWARD Kir3 CHANNEL ACTIVATION?}

Although DORs agonists effectively alleviate chronic pain and have milder side effects than ligands acting at other opioid receptors (Gallantine and Meert, 2005; Feng et al., 2006; Codd et al., 2009), their potential for tolerance (Pradhan et al., 2010; Audet et al., 2012) limits their possible application as therapeutic agents. Given the contribution of cyclase pathway adaptations to the development of this side effect (Javed et al., 2004; He and Whistler, 2007; Bobeck et al., 2014), biasing pharmacological stimulus toward Kir3 channel activation and/or away from cyclase modulation was proposed as a rational means of reducing tolerance. Importantly, together with voltage-gated $\mathrm{K}^{+}$channels (Wimpey and Chavkin, 1991; Moore et al., 1994) and $\beta$ arrs, Kir3

A
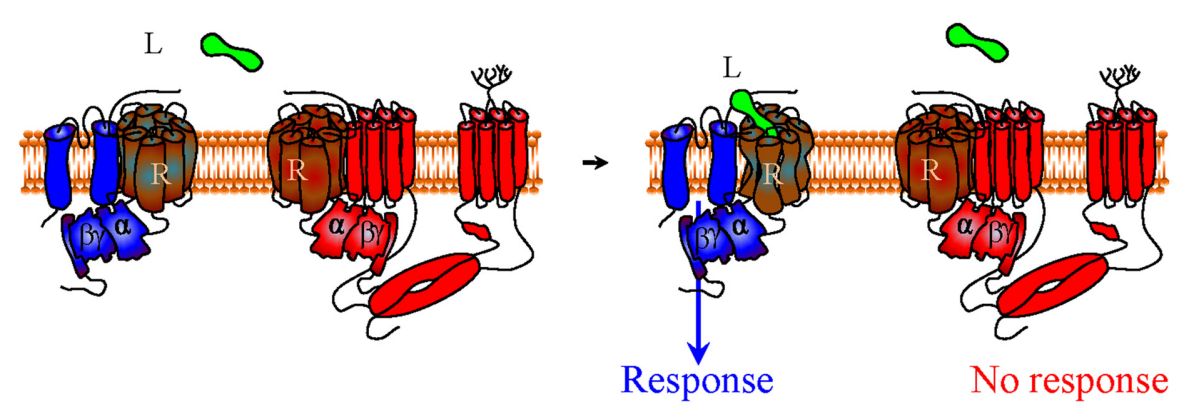

B
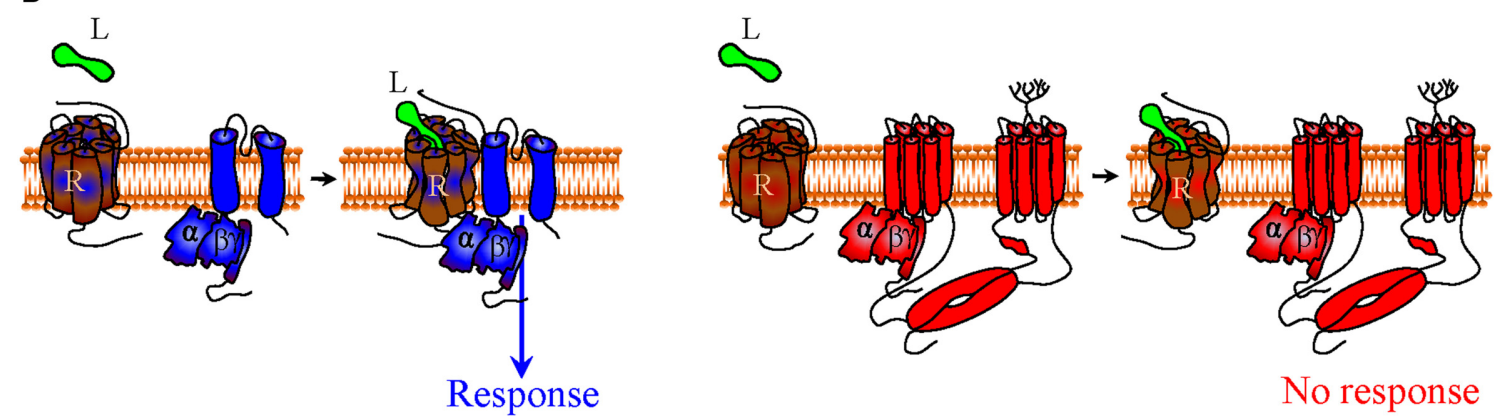

No response

FIGURE 2 | Functional selectivity due to biased signaling of orthosteric receptor agonists. Within the context of a precoupling model, an agonist that preferentially recognizes the receptor conformation stabilized by signaling partners in the channel complex over the receptor state stabilized within the cyclase complex would display bias toward channel signaling (A). In a restricted collision model $\mathrm{G}$ proteins and effectors coexist as a preformed complex that is activated through collision with the agonist-bound receptor. In this context bias toward Kir3 signaling can take place if the agonist-bound receptor displays higher affinity for $\mathrm{G} \alpha \beta \gamma$-Kir3 than $\mathrm{G} \alpha \beta \gamma$-cyclase complexes (B). To aid visualization, Kir3 channel is shown in blue and adenylyl cyclase in red. 
channels may also participate in hippocampal hyperexcitability (Luscher et al., 1997) induced by certain DOR ligands (Broom et al., 2002; Jutkiewicz et al., 2005). Depending on the degree of Kir3 involvement in this side effect, the incidence of seizures could increase for DOR ligands with Kir3 signaling bias. If this were the case, the alternative strategy based on obliteration of cyclase modulation would be of choice.

Biased agonism refers to the ability of orthosteric receptor ligands to selectively engage the activity of a distinct set of signaling partners over another (Urban et al., 2007), a type of selectivity that ensues from the stabilization of receptor conformations which activate a specific effector(s) while sparing the rest (Kenakin and Miller, 2010). Functional selectivity may also be indirect, driven by allosteric ligands (Leach et al., 2007; Kenakin, 2008). Sodium is an allosteric modulator of DORs and manipulation of its binding site provides an example of how allosteric influences may direct pharmacological stimuli toward different effectors (Fenalti et al., 2014). In particular, mutation of one of the residues (Asn131) in the first coordination shell of the $\mathrm{Na}^{+}$ion produced an "efficacy switch" that changed DOR signal-

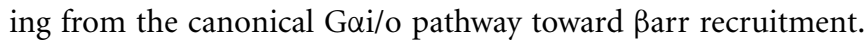
Furthermore, this effect was ligand sensitive since agonists lost Gai signaling while the antagonist naltrindole gained the ability to recruit $\beta$ arr (Fenalti et al., 2014). Hence, by stabilizing receptor conformations that differentially favor one orthosteric response over another, allosteric modulation of receptor conformations offer a great potential for directing pharmacological stimuli toward a desired response.

Let us first consider signaling bias within the context of the traditional shuttling-collision model. According to this paradigm the agonist interacts with a receptor which then travels within the membrane to interact and activate a $G$ protein whose $G \alpha$ and $\mathrm{G} \beta \gamma$ subunits subsequently dissociate from the ligand-receptor complex to find and activate an effector (Orly and Schramm, 1976; Tolkovsky and Levitzki, 1978; Gilman, 1987; Bourne, 1997). Because in this model receptor and effector do not simultaneously interact with the $\mathrm{G}$ protein, the paradigm does not provide for a "memory" that would allow transferring conformational information codified by the agonist-bound receptor beyond the transducer stage. However, more recent spectroscopic studies of receptor- $G$ protein-effector interaction point to greater restriction in mobility where $G$ protein and effectors would be spontaneously coupled (Lohse et al., 2012). Moreover, independent of whether receptors form part of this constitutive complex or not, evidence analyzed in the previous section indicated that all three species may persistently associate during signaling. This association provides the basis for a "conformational memory" and the possibility of exploring novel bias strategies to specifically direct the pharmacological stimulus of a given receptor (in this case DORs) to a desired $G$ protein coupled effector (Kir3 channels).

Being allosteric proteins (Kenakin and Miller, 2010), the conformation adopted by the receptor will not be solely determined
A
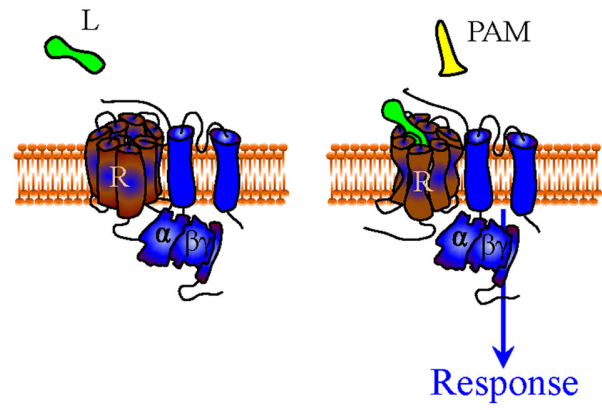

B

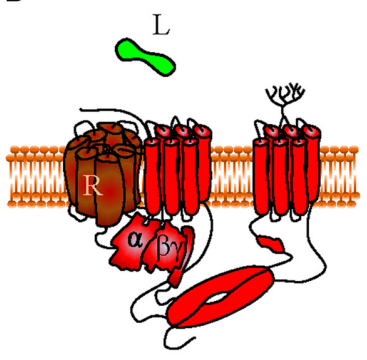

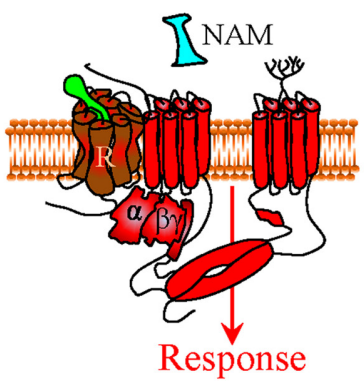

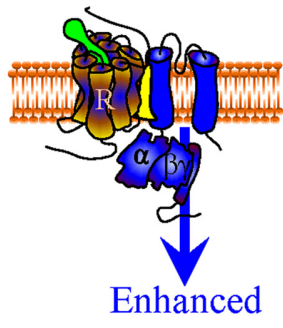

response

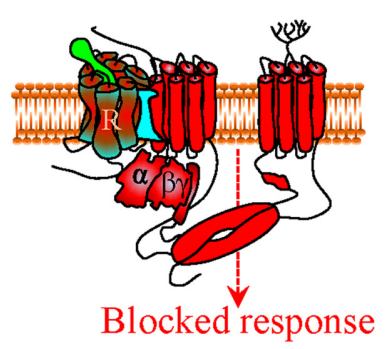

FIGURE 3 | Mechanisms of indirect bias involving allosteric modulators that specifically recognize a complex of desired composition. In a precoupling model or in a restricted collision model receptors, G proteins and effectors may all persistently associate during signaling. Within this context (only precoupling model represented in figure), small positive allosteric modulators (PAM) that specifically recognize the interface between DORs and Kir3 channels (in blue) may specifically bias signaling of DOR orthosteric agonists toward this effector by stabilizing the complex and/or favoring channel opening (A). A negative allosteric modulator (NAM) that recognizes the DOR-adenylyl cyclase (in red) interface could distinctively block cAMP inhibition by the activated DOR, also allowing for bias in favor of channel effectors (B). 
by orthosteric agonist binding, but also by its interaction with its cytosolic (G protein subunits) and membrane (Kir3 or cyclase) signaling partners, which therefore function as natural allosteric modulators. In cases where signaling complexes exist before activation, selectivity favoring Kir3 vs. cyclase signaling could be achieved by designing orthosteric ligands that display higher affinity for the conformation adopted by the receptor when contained within a Kir3 signaling complex than the one induced by its inclusion into cyclase multimers (Figure $2 \mathbf{A}$ ). The idea that orthosteric agonists can indeed be tailored to specifically recognize receptors in association with distinct signaling partners is supported by studies indicating that the pharmacological properties of receptors contained in homodimers are different from those displayed by the same receptor when it is part of an heterodimer (Jordan and Devi, 1999; Waldhoer et al., 2005). Alternatively, if the complex is formed during signaling, bias toward Kir3 channel effectors would depend on the agonist's ability to stabilize a receptor conformation whose affinity for the $G$ protein/Kir3 complex is higher than the one displayed for the $G$ protein/cyclase complex (Figure 2B).

In addition, if at rest and/or during signaling receptors, $G$ proteins and effectors associate through a distinct network of conformational influences, it is also conceivable that the pharmacological stimulus that is produced by an orthosteric ligand could be influenced by small allosteric modulators that specifically recognize the complex with the desired combination of DORs,

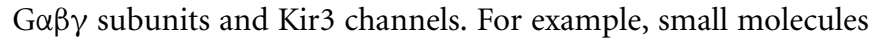
that could bind the interface of DORs and Kir3 subunits to stabilize the complex and/or favor channel opening (positive allosteric modulators), would be of particular interest since they could selectively enhance Kir3 signaling by DORs and no other receptors that modulate this effector (Figure 3A). Alternatively, a negative allosteric modulator that recognizes the DOR/adenylyl cyclase interface could distinctively block cAMP inhibition by this receptor, resulting in another desired type of bias (Figure 3B). Finally, a variation of this strategy would be to design complexselective allosteric agonists which are able to initiate signaling, independent of whether the orthosteric ligand is present or not (Figure 4A), or only when it is present for the case of restricted collision (Figure 4B). Such type of ligand could putatively recognize and stabilize the interface formed between the C-terminus of the activated Gai/o subunit, the channel N-terminus and the third intracellular loop of the receptor. Admittedly, the structural information required for designing these compounds is not yet available but should become available once receptor/G proteins complexes are co-crystallized with their effectors.

In summary, we have analyzed evidence indicating that Kir3 channels are mediators of opioid analgesia. While they play a considerable role in undesired effects of MOR agonists, their contribution to those of DOR ligands is limited. Biasing DOR responses in favor of Kir3 channels and away from cyclase inhibition was suggested as a means of controlling analgesic tolerance

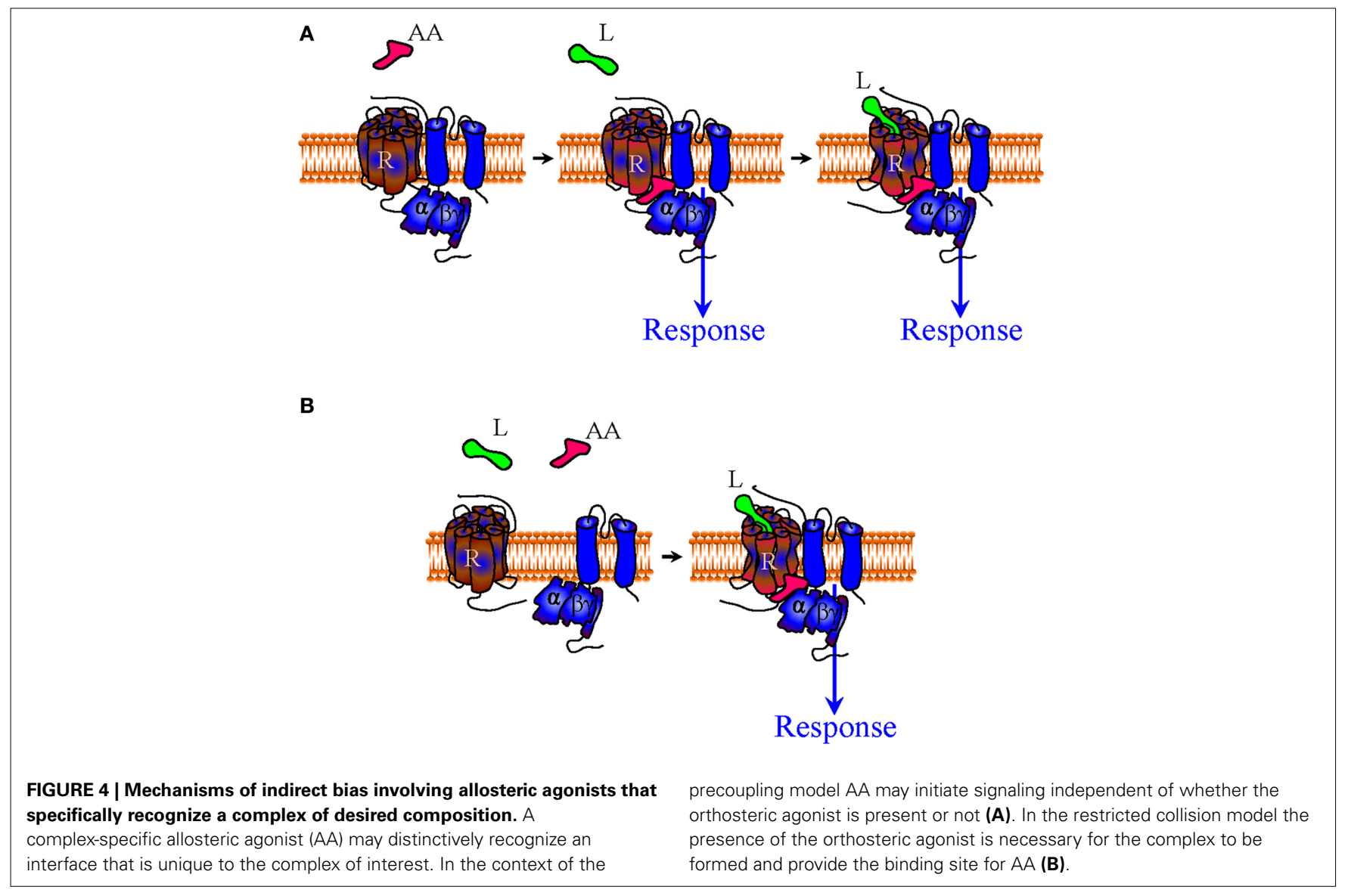


of DOR agonists, a side effect that limits their potential therapeutic application. Different modalities of GPCR association with G proteins and effectors were discussed, and putative bias strategies to ensure specific activation of a desired combination of receptors (DORs) and effectors (Kir3 channels) were provided.

\section{ACKNOWLEDGMENTS}

This work was supported by grants from the Natural Sciences and Engineering Research Council of Canada (NSERC) to Graciela Pineyro [311997]. Karim Nagi holds a studentship from SteJustine Hospital Research Center and the Faculty of Graduate and Postdoctoral Studies, University of Montreal.

\section{REFERENCES}

Andrade, A., Denome, S., Jiang, Y. Q., Marangoudakis, S., and Lipscombe, D. (2010). Opioid inhibition of N-type $\mathrm{Ca}^{2+}$ channels and spinal analgesia couple to alternative splicing. Nat. Neurosci. 13, 1249-1256. doi: 10.1038/ nn. 2643

Audet, N., Charfi, I., Mnie-Filali, O., Amraei, M., Chabot-Dore, A. J., Millecamps, M., et al. (2012). Differential association of receptor-Gbetagamma complexes with beta-arrestin2 determines recycling bias and potential for tolerance of delta opioid receptor agonists. J. Neurosci. 32, 4827-4840. doi: 10.1523/JNEUROSCI.3734-11.2012

Audet, N., Gales, C., Archer-Lahlou, E., Vallieres, M., Schiller, P. W., Bouvier, M., et al. (2008). Bioluminescence resonance energy transfer assays reveal ligand-specific conformational changes within preformed signaling complexes containing delta-opioid receptors and heterotrimeric $\mathrm{G}$ proteins. J. Biol. Chem. 283, 15078-15088. doi: 10.1074/jbc.M707941200

Ballantyne, J. C., and Shin, N. S. (2008). Efficacy of opioids for chronic pain: a review of the evidence. Clin. J. Pain 24, 469-478. doi: 10.1097/AJP.0b013e3 $1816 \mathrm{~b} 2 \mathrm{f} 26$

Banks, M. L., Roma, P. G., Folk, J. E., Rice, K. C., and Negus, S. S. (2011). Effects of the delta-opioid agonist SNC80 on the abuse liability of methadone in rhesus monkeys: a behavioral economic analysis. Psychopharmacology (Berl) 216, 431-439. doi: 10.1007/s00213-011-2235-2

Bardoni, R., Tawfik, V. L., Wang, D., Francois, A., Solorzano, C., Shuster, S. A., et al. (2014). Delta opioid receptors presynaptically regulate cutaneous mechanosensory neuron input to the spinal cord dorsal horn. Neuron 81, 1312-1327. doi: 10.1016/j.neuron.2014.01.044

Berlin, S., Keren-Raifman, T., Castel, R., Rubinstein, M., Dessauer, C. W., Ivanina, T., et al. (2010). G alpha(i) and $G$ betagamma jointly regulate the conformations of a $G$ betagamma effector, the neuronal $G$ protein-activated $\mathrm{K}^{+}$channel (GIRK). J. Biol. Chem. 285, 6179-6185. doi: 10.1074/jbc.M109. 085944

Berlin, S., Tsemakhovich, V. A., Castel, R., Ivanina, T., Dessauer, C. W., KerenRaifman, T., et al. (2011). Two distinct aspects of coupling between Galpha(i) protein and $\mathrm{G}$ protein-activated $\mathrm{K}^{+}$channel (GIRK) revealed by fluorescently labeled Galpha(i3) protein subunits. J. Biol. Chem. 286, 33223-33235. doi: 10.1074/jbc.M111.271056

Bettahi, I., Marker, C. L., Roman, M. I., and Wickman, K. (2002). Contribution of the Kir3.1 subunit to the muscarinic-gated atrial potassium channel IKACh. J. Biol. Chem. 277, 48282-48288. doi: 10.1074/jbc.M209599200

Blednov, Y. A., Stoffel, M., Alva, H., and Harris, R. A. (2003). A pervasive mechanism for analgesia: activation of GIRK2 channels. Proc. Natl. Acad. Sci. U.S.A. 100, 277-282. doi: 10.1073/pnas.012682399

Blednov, Y. A., Stoffel, M., Chang, S. R., and Harris, R. A. (2001). GIRK2 deficient mice. Evidence for hyperactivity and reduced anxiety. Physiol. Behav. 74, 109-117. doi: 10.1016/S0031-9384(01)00555-8

Bobeck, E. N., Chen, Q., Morgan, M. M., and Ingram, S. L. (2014). Contribution of adenylyl cyclase modulation of pre- and postsynaptic GABA neurotransmission to morphine antinociception and tolerance. Neuropsychopharmacology. doi: 10.1038/npp.2014.62. [Epub ahead of print].

Bonci, A., and Williams, J. T. (1997). Increased probability of GABA release during withdrawal from morphine. J. Neurosci. 17, 796-803.

Bourne, H. R. (1997). How receptors talk to trimeric G proteins. Curr. Opin. Cell Biol. 9, 134-142. doi: 10.1016/S0955-0674(97)80054-3
Broom, D. C., Nitsche, J. F., Pintar, J. E., Rice, K. C., Woods, J. H., and Traynor, J. R. (2002). Comparison of receptor mechanisms and efficacy requirements for delta-agonist-induced convulsive activity and antinociception in mice. J. Pharmacol. Exp. Ther. 303, 723-729. doi: 10.1124/jpet.102.036525

Bruchas, M. R., and Chavkin, C. (2010). Kinase cascades and ligand-directed signaling at the kappa opioid receptor. Psychopharmacology (Berl) 210, 137-147. doi: 10.1007/s00213-010-1806-y

Bruchas, M. R., Land, B. B., Aita, M., Xu, M., Barot, S. K., Li, S., et al. (2007). Stress-induced p38 mitogen-activated protein kinase activation mediates kappa-opioid-dependent dysphoria. J. Neurosci. 27, 11614-11623. doi: 10.1523/JNEUROSCI.3769-07.2007

Bruehl, S., Denton, J. S., Lonergan, D., Koran, M. E., Chont, M., Sobey, C., et al. (2013). Associations between KCNJ6 (GIRK2) gene polymorphisms and painrelated phenotypes. Pain 154, 2853-2859. doi: 10.1016/j.pain.2013.08.026

Bunemann, M., Frank, M., and Lohse, M. J. (2003). Gi protein activation in intact cells involves subunit rearrangement rather than dissociation. Proc. Natl. Acad. Sci. U.S.A. 100, 16077-16082. doi: 10.1073/pnas.2536719100

Cao, J. L., Vialou, V. F., Lobo, M. K., Robison, A. J., Neve, R. L., Cooper, D. C., et al. (2010). Essential role of the cAMP-cAMP response-element binding protein pathway in opiate-induced homeostatic adaptations of locus coeruleus neurons. Proc. Natl. Acad. Sci. U.S.A. 107, 17011-17016. doi: 10.1073/pnas.10100 77107

Charbogne, P., Kieffer, B. L., and Befort, K. (2014). 15 years of genetic approaches in vivo for addiction research: opioid receptor and peptide gene knockout in mouse models of drug abuse. Neuropharmacology 76(Pt B), 204-217. doi: 10.1016/j.neuropharm.2013.08.028

Cheng, P. Y., Wu, D., Soong, Y., McCabe, S., Decena, J. A., and Szeto, H. H. (1993). Role of mu 1- and delta-opioid receptors in modulation of fetal EEG and respiratory activity. Am. J. Physiol. 265, R433-R438.

Christie, M. J. (2008). Cellular neuroadaptations to chronic opioids: tolerance, withdrawal and addiction. Br. J. Pharmacol. 154, 384-396. doi: 10.1038/bjp.2008.100

Chung, M. K., Cho, Y. S., Bae, Y. C., Lee, J., Zhang, X., and Ro, J. Y. (2013). Peripheral G protein-coupled inwardly rectifying potassium channels are involved in delta-opioid receptor-mediated anti-hyperalgesia in rat masseter muscle. Eur. J. Pain 18, 29-38. doi: 10.1002/j.1532-2149.2013.00343.x

Chu Sin Chung, P., and Kieffer, B. L. (2013). Delta opioid receptors in brain function and diseases. Pharmacol. Ther. 140, 112-120. doi: 10.1016/j.pharmthera. 2013.06.003

Ciruela, F., Fernandez-Duenas, V., Sahlholm, K., Fernandez-Alacid, L., Nicolau, J. C., Watanabe, M., et al. (2010). Evidence for oligomerization between GABAB receptors and GIRK channels containing the GIRK1 and GIRK3 subunits. Eur. J. Neurosci. 32, 1265-1277. doi: 10.1111/j.1460-9568.2010.07356.x

Clancy, S. M., Boyer, S. B., and Slesinger, P. A. (2007). Coregulation of natively expressed pertussis toxin-sensitive muscarinic receptors with Gprotein-activated potassium channels. J. Neurosci. 27, 6388-6399. doi: 10.1523/ JNEUROSCI.1190-07.2007

Clancy, S. M., Fowler, C. E., Finley, M., Suen, K. F., Arrabit, C., Berton, F., et al. (2005). Pertussis-toxin-sensitive Galpha subunits selectively bind to C-terminal domain of neuronal GIRK channels: evidence for a heterotrimeric G-protein-channel complex. Mol. Cell. Neurosci. 28, 375-389. doi: 10.1016/j.mcn.2004.10.009

Codd, E. E., Carson, J. R., Colburn, R. W., Stone, D. J., Van Besien, C. R., Zhang, S. P., et al. (2009). JNJ-20788560 [9-(8-azabicyclo[3.2.1]oct-3ylidene)-9H-xanthene-3-carboxylic acid diethylamide], a selective delta opioid receptor agonist, is a potent and efficacious antihyperalgesic agent that does not produce respiratory depression, pharmacologic tolerance, or physical dependence. J. Pharmacol. Exp. Ther. 329, 241-251. doi: 10.1124/jpet.108. 146969

Cooper, A., Grigoryan, G., Guy-David, L., Tsoory, M. M., Chen, A., and Reuveny, E. (2012). Trisomy of the $\mathrm{G}$ protein-coupled $\mathrm{K}^{+}$channel gene, Kcnj6, affects reward mechanisms, cognitive functions, and synaptic plasticity in mice. Proc. Natl. Acad. Sci. U.S.A. 109, 2642-2647. doi: 10.1073/pnas.1109099109

Cowan, A., Zhu, X. Z., Mosberg, H. I., Omnaas, J. R., and Porreca, F. (1988). Direct dependence studies in rats with agents selective for different types of opioid receptor. J. Pharmacol. Exp. Ther. 246, 950-955.

Cruz, H. G., Ivanova, T., Lunn, M. L., Stoffel, M., Slesinger, P. A., and Luscher, C. (2004). Bi-directional effects of GABA(B) receptor agonists on the mesolimbic dopamine system. Nat. Neurosci. 7, 153-159. doi: 10.1038/nn1181 
De Sarro, G. B., Marra, R., Spagnolo, C., and Nistico, G. (1992). Delta opioid receptors mediate seizures produced by intrahippocampal injection of ala-deltorphin in rats. Funct. Neurol. 7, 235-238.

Dewire, S. M., Yamashita, D. S., Rominger, D. H., Liu, G., Cowan, C. L., Graczyk, T. M., et al. (2013). A G protein-biased ligand at the mu-opioid receptor is potently analgesic with reduced gastrointestinal and respiratory dysfunction compared with morphine. J. Pharmacol. Exp. Ther. 344, 708-717. doi: 10.1124/jpet.112.201616

Do Carmo, G. P., Folk, J. E., Rice, K. C., Chartoff, E., Carlezon, W. A. Jr., and Negus, S. S. (2009). The selective non-peptidic delta opioid agonist SNC80 does not facilitate intracranial self-stimulation in rats. Eur. J. Pharmacol. 604, 58-65. doi: 10.1016/j.ejphar.2008.12.021

Drake, C. T., Chavkin, C., and Milner, T. A. (2007). Opioid systems in the dentate gyrus. Prog. Brain Res. 163, 245-263. doi: 10.1016/S0079-6123(07)63015-5

Falkenburger, B. H., Jensen, J. B., and Hille, B. (2010). Kinetics of M1 muscarinic receptor and $\mathrm{G}$ protein signaling to phospholipase $\mathrm{C}$ in living cells. J. Gen. Physiol. 135, 81-97. doi: 10.1085/jgp.200910344

Fenalti, G., Giguere, P. M., Katritch, V., Huang, X. P., Thompson, A. A., Cherezov, V., et al. (2014). Molecular control of delta-opioid receptor signalling. Nature 506, 191-196. doi: 10.1038/nature12944

Feng, P., Rahim, R. T., Cowan, A., Liu-Chen, L. Y., Peng, X., Gaughan, J., et al. (2006). Effects of mu, kappa or delta opioids administered by pellet or pump on oral Salmonella infection and gastrointestinal transit. Eur. J. Pharmacol. 534, 250-257. doi: 10.1016/j.ejphar.2006.01.048

Fernandez-Alacid, L., Aguado, C., Ciruela, F., Martin, R., Colon, J., Cabanero, M. J., et al. (2009). Subcellular compartment-specific molecular diversity of pre- and post-synaptic GABA-activated GIRK channels in Purkinje cells. J. Neurochem. 110, 1363-1376. doi: 10.1111/j.1471-4159.2009.06229.x

Fernandez-Alacid, L., Watanabe, M., Molnar, E., Wickman, K., and Lujan, R. (2011). Developmental regulation of $\mathrm{G}$ protein-gated inwardly-rectifying $\mathrm{K}^{+}$ (GIRK/Kir3) channel subunits in the brain. Eur. J. Neurosci. 34, 1724-1736. doi: 10.1111/j.1460-9568.2011.07886.x

Finley, M., Arrabit, C., Fowler, C., Suen, K. F., and Slesinger, P. A. (2004). betaLbetaM loop in the $\mathrm{C}$-terminal domain of $\mathrm{G}$ protein-activated inwardly rectifying $\mathrm{K}(+)$ channels is important for $\mathrm{G}$ (betagamma) subunit activation. J. Physiol. 555, 643-657. doi: 10.1113/jphysiol.2003.056101

Ford, C. E., Skiba, N. P., Bae, H., Daaka, Y., Reuveny, E., Shekter, L. R., et al. (1998). Molecular basis for interactions of $G$ protein betagamma subunits with effectors. Science 280, 1271-1274. doi: 10.1126/science.280.53 67.1271

Fourie, C., Li, D., and Montgomery, J. M. (2014). The anchoring protein SAP97 influences the trafficking and localisation of multiple membrane channels. Biochim. Biophys. Acta 1838, 589-594. doi: 10.1016/j.bbamem.2013.03.015

Gales, C., Rebois, R. V., Hogue, M., Trieu, P., Breit, A., Hebert, T. E., et al. (2005). Real-time monitoring of receptor and G-protein interactions in living cells. Nat. Methods 2, 177-184. doi: 10.1038/nmeth743

Gales, C., Van Durm, J. J., Schaak, S., Pontier, S., Percherancier, Y., Audet, M., et al. (2006). Probing the activation-promoted structural rearrangements in preassembled receptor-G protein complexes. Nat. Struct. Mol. Biol. 13, 778-786. doi: $10.1038 / \mathrm{nsmb} 1134$

Gallantine, E. L., and Meert, T. F. (2005). A comparison of the antinociceptive and adverse effects of the mu-opioid agonist morphine and the delta-opioid agonist SNC80. Basic Clin. Pharmacol. Toxicol. 97, 39-51. doi: 10.1111/j.17427843.2005.pto_97107.x

Gao, X. F., Zhang, H. L., You, Z. D., Lu, C. L., and He, C. (2007). G protein-coupled inwardly rectifying potassium channels in dorsal root ganglion neurons. Acta Pharmacol. Sin. 28, 185-190. doi: 10.1111/j.1745-7254.2007.00478.x

Gaveriaux-Ruff, C., and Kieffer, B. L. (2011). Delta opioid receptor analgesia: recent contributions from pharmacology and molecular approaches. Behav. Pharmacol. 22, 405-414. doi: 10.1097/FBP.0b013e32834a1f2c

Gendron, L., Lucido, A. L., Mennicken, F., O’Donnell, D., Vincent, J. P., Stroh, T., et al. (2006). Morphine and pain-related stimuli enhance cell surface availability of somatic delta-opioid receptors in rat dorsal root ganglia. J. Neurosci. 26, 953-962. doi: 10.1523/JNEUROSCI.3598-05.2006

Gilman, A. G. (1987). G proteins: transducers of receptor-generated signals. Annu. Rev. Biochem. 56, 615-649. doi: 10.1146/annurev.bi.56.070187.003151

Glaum, S. R., Miller, R. J., and Hammond, D. L. (1994). Inhibitory actions of delta 1-, delta 2-, and mu-opioid receptor agonists on excitatory transmission in lamina II neurons of adult rat spinal cord. J. Neurosci. 14, 4965-4971.
Goldenberg, D. L. (2010). Pain/Depression dyad: a key to a better understanding and treatment of functional somatic syndromes. Am. J. Med. 123, 675-682. doi: 10.1016/j.amjmed.2010.01.014

Gonzalez-Rodriguez, S., Hidalgo, A., Baamonde, A., and Menendez, L. (2010). Involvement of Gi/o proteins and GIRK channels in the potentiation of morphine-induced spinal analgesia in acutely inflamed mice. Naunyn Schmiedeberg's Arch. Pharmacol. 381, 59-71. doi: 10.1007/s00210-0090471-3

Gonzalez-Rodriguez, S., Llames, S., Hidalgo, A., Baamonde, A., and Menendez, L. (2012). Potentiation of acute morphine-induced analgesia measured by a thermal test in bone cancer-bearing mice. Fundam. Clin. Pharmacol. 26, 363-372. doi: 10.1111/j.1472-8206.2010.00921.x

Gross, W., and Lohse, M. J. (1991). Mechanism of activation of A2 adenosine receptors. II. A restricted collision-coupling model of receptor-effector interaction. Mol. Pharmacol. 39, 524-530.

Gysling, K., and Wang, R. Y. (1983). Morphine-induced activation of A10 dopamine neurons in the rat. Brain Res. 277, 119-127. doi: 10.1016/00068993(83)90913-7

Han, M. H., Bolanos, C. A., Green, T. A., Olson, V. G., Neve, R. L., Liu, R. J., et al. (2006). Role of cAMP response element-binding protein in the rat locus ceruleus: regulation of neuronal activity and opiate withdrawal behaviors. J. Neurosci. 26, 4624-4629. doi: 10.1523/JNEUROSCI.4701-05.2006

Hassan, A. H., Ableitner, A., Stein, C., and Herz, A. (1993). Inflammation of the rat paw enhances axonal transport of opioid receptors in the sciatic nerve and increases their density in the inflamed tissue. Neuroscience 55, 185-195. doi: 10.1016/0306-4522(93)90465-R

He, C., Yan, X., Zhang, H., Mirshahi, T., Jin, T., Huang, A., et al. (2002) Identification of critical residues controlling $\mathrm{G}$ protein-gated inwardly rectifying $\mathrm{K}(+)$ channel activity through interactions with the beta gamma subunits of G proteins. J. Biol. Chem. 277, 6088-6096. doi: 10.1074/jbc.M104851200

He, C., Zhang, H., Mirshahi, T., and Logothetis, D. E. (1999). Identification of a potassium channel site that interacts with $G$ protein betagamma subunits to mediate agonist-induced signaling. J. Biol. Chem. 274, 12517-12524.

He, L., and Whistler, J. L. (2007). The biochemical analysis of methadone modulation on morphine-induced tolerance and dependence in the rat brain. Pharmacology 79, 193-202. doi: 10.1159/000100893

Hearing, M., Kotecki, L., Marron Fernandez De Velasco, E., Fajardo-Serrano, A., Chung, H. J., Lujan, R., et al. (2013). Repeated cocaine weakens GABA(B)-Girk signaling in layer 5/6 pyramidal neurons in the prelimbic cortex. Neuron 80 , 159-170. doi: 10.1016/j.neuron.2013.07.019

Hein, P., Frank, M., Hoffmann, C., Lohse, M. J., and Bunemann, M. (2005). Dynamics of receptor/G protein coupling in living cells. EMBO J. 24, 4106-4114. doi: 10.1038/sj.emboj.7600870

Hein, P., Rochais, F., Hoffmann, C., Dorsch, S., Nikolaev, V. O., Engelhardt, S., et al. (2006). Gs activation is time-limiting in initiating receptor-mediated signaling. J. Biol. Chem. 281, 33345-33351. doi: 10.1074/jbc.M606713200

Heinke, B., Gingl, E., and Sandkuhler, J. (2011). Multiple targets of mu-opioid receptor-mediated presynaptic inhibition at primary afferent Adelta- and Cfibers. J. Neurosci. 31, 1313-1322. doi: 10.1523/JNEUROSCI.4060-10.2011

Hibino, H., Inanobe, A., Furutani, K., Murakami, S., Findlay, I., and Kurachi, Y. (2010). Inwardly rectifying potassium channels: their structure, function, and physiological roles. Physiol. Rev. 90, 291-366. doi: 10.1152/physrev.00021.2009

Hibino, H., Inanobe, A., Tanemoto, M., Fujita, A., Doi, K., Kubo, T., et al. (2000). Anchoring proteins confer G protein sensitivity to an inwardrectifier $\mathrm{K}(+)$ channel through the GK domain. EMBO J. 19, 78-83. doi: 10.1093/emboj/19.1.78

Huang, C. L., Jan, Y. N., and Jan, L. Y. (1997). Binding of the G protein betagamma subunit to multiple regions of $\mathrm{G}$ protein-gated inward-rectifying $\mathrm{K}^{+}$channels. FEBS Lett. 405, 291-298. doi: 10.1016/S0014-5793(97)00197-X

Huang, C. L., Slesinger, P. A., Casey, P. J., Jan, Y. N., and Jan, L. Y. (1995). Evidence that direct binding of G beta gamma to the GIRK1 G protein-gated inwardly rectifying $\mathrm{K}^{+}$channel is important for channel activation. Neuron 15 , 1133-1143.

Ikeda, K., Kobayashi, T., Kumanishi, T., Niki, H., and Yano, R. (2000). Involvement of G-protein-activated inwardly rectifying $\mathrm{K}$ (GIRK) channels in opioid-induced analgesia. Neurosci. Res. 38, 113-116. doi: 10.1016/S01680102(00)00144-9

Ikeda, K., Kobayashi, T., Kumanishi, T., Yano, R., Sora, I., and Niki, H. (2002). Molecular mechanisms of analgesia induced by opioids and ethanol: is the 
GIRK channel one of the keys? Neurosci. Res. 44, 121-131. doi: 10.1016/S01680102(02)00094-9

Inanobe, A., Yoshimoto, Y., Horio, Y., Morishige, K. I., Hibino, H., Matsumoto, S., et al. (1999). Characterization of G-protein-gated $\mathrm{K}^{+}$channels composed of Kir3.2 subunits in dopaminergic neurons of the substantia nigra. J. Neurosci. 19, 1006-1017.

Ivanina, T., Rishal, I., Varon, D., Mullner, C., Frohnwieser-Steinecke, B., Schreibmayer, W., et al. (2003). Mapping the Gbetagamma-binding sites in GIRK1 and GIRK2 subunits of the G protein-activated $\mathrm{K}^{+}$channel. J. Biol. Chem. 278, 29174-29183. doi: 10.1074/jbc.M304518200

Ivanina, T., Varon, D., Peleg, S., Rishal, I., Porozov, Y., Dessauer, C. W., et al. (2004). Galphai1 and Galphai3 differentially interact with, and regulate, the G protein-activated $\mathrm{K}^{+}$channel. J. Biol. Chem. 279, 17260-17268. doi: 10.1074/jbc.M313425200

Javed, R. R., Dewey, W. L., Smith, P. A., and Smith, F. L. (2004). PKC and PKA inhibitors reverse tolerance to morphine-induced hypothermia and supraspinal analgesia in mice. Eur. J. Pharmacol. 492, 149-157. doi: 10.1016/j.ejphar.2004.03.061

Jensen, J. B., Lyssand, J. S., Hague, C., and Hille, B. (2009). Fluorescence changes reveal kinetic steps of muscarinic receptor-mediated modulation of phosphoinositides and Kv7.2/7.3 K ${ }^{+}$channels. J. Gen. Physiol. 133, 347-359. doi: 10.1085/jgp.200810075

Johnson, S. W., and North, R. A. (1992). Opioids excite dopamine neurons by hyperpolarization of local interneurons. J. Neurosci. 12, 483-488.

Jordan, B. A., and Devi, L. A. (1999). G-protein-coupled receptor heterodimerization modulates receptor function. Nature 399, 697-700.

Jutkiewicz, E. M., Baladi, M. G., Folk, J. E., Rice, K. C., and Woods, J. H. (2006). The convulsive and electroencephalographic changes produced by nonpeptidic delta-opioid agonists in rats: comparison with pentylenetetrazol. J. Pharmacol. Exp. Ther. 317, 1337-1348. doi: 10.1124/jpet.105.095810

Jutkiewicz, E. M., Rice, K. C., Traynor, J. R., and Woods, J. H. (2005). Separation of the convulsions and antidepressant-like effects produced by the deltaopioid agonist SNC80 in rats. Psychopharmacology (Berl) 182, 588-596. doi: 10.1007/s00213-005-0138-9

Kalso, E., Edwards, J. E., Moore, R. A., and McQuay, H. J. (2004). Opioids in chronic non-cancer pain: systematic review of efficacy and safety. Pain 112, 372-380. doi: 10.1016/j.pain.2004.09.019

Kawano, T., Zhao, P., Floreani, C. V., Nakajima, Y., Kozasa, T., and Nakajima, S. (2007). Interaction of Galphaq and Kir3, G protein-coupled inwardly rectifying potassium channels. Mol. Pharmacol. 71, 1179-1184. doi: 10.1124/mol.106.032508

Kenakin, T. (2008). Functional selectivity in GPCR modulator screening. Comb. Chem. High Throughput Screen. 11, 337-343. doi: 10.2174/1386207087 84534824

Kenakin, T., and Miller, L. J. (2010). Seven transmembrane receptors as shapeshifting proteins: the impact of allosteric modulation and functional selectivity on new drug discovery. Pharmacol. Rev. 62, 265-304. doi: 10.1124/pr.108.000992

Kenakin, T., and Onaran, O. (2002). The ligand paradox between affinity and efficacy: can you be there and not make a difference? Trends Pharmacol. Sci. 23, 275-280. doi: 10.1016/S0165-6147(02)02036-9

Kieffer, B. L., and Gaveriaux-Ruff, C. (2002). Exploring the opioid system by gene knockout. Prog. Neurobiol. 66, 285-306. doi: 10.1016/S0301-0082(02) 00008-4

Koyrakh, L., Lujan, R., Colon, J., Karschin, C., Kurachi, Y., Karschin, A., et al. (2005). Molecular and cellular diversity of neuronal G-protein-gated potassium channels. J. Neurosci. 25, 11468-11478. doi: 10.1523/JNEUROSCI.3484-05.2005

Krapivinsky, G., Kennedy, M. E., Nemec, J., Medina, I., Krapivinsky, L., and Clapham, D. E. (1998). Gbeta binding to GIRK4 subunit is critical for G protein-gated $\mathrm{K}^{+}$channel activation. J. Biol. Chem. 273, 16946-16952. doi: 10.1074/jbc.273.27.16946

Kunkel, M. T., and Peralta, E. G. (1995). Identification of domains conferring G protein regulation on inward rectifier potassium channels. Cell 83, 443-449. doi: 10.1016/0092-8674(95)90122-1

Laurent, V., Leung, B., Maidment, N., and Balleine, B. W. (2012). mu- and delta-opioid-related processes in the accumbens core and shell differentially mediate the influence of reward-guided and stimulus-guided decisions on choice. J. Neurosci. 32, 1875-1883. doi: 10.1523/JNEUROSCI.4688-11.2012

Lavine, N., Ethier, N., Oak, J. N., Pei, L., Liu, F., Trieu, P., et al. (2002). G protein-coupled receptors form stable complexes with inwardly rectifying potassium channels and adenylyl cyclase. J. Biol. Chem. 277, 46010-46019. doi: 10.1074/jbc.M205035200

Leach, K., Sexton, P. M., and Christopoulos, A. (2007). Allosteric GPCR modulators: taking advantage of permissive receptor pharmacology. Trends Pharmacol. Sci. 28, 382-389. doi: 10.1016/j.tips.2007.06.004

Le Bourdonnec, B., Windh, R. T., Ajello, C. W., Leister, L. K., Gu, M., Chu, G. H., et al. (2008). Potent, orally bioavailable delta opioid receptor agonists for the treatment of pain: discovery of N,N-diethyl-4-(5-hydroxyspiro[chromene2,4'-piperidine]-4-yl)benzamide (ADL5859). J. Med. Chem. 51, 5893-5896. doi: $10.1021 / j m 8008986$

Le Merrer, J., Becker, J. A., Befort, K., and Kieffer, B. L. (2009). Reward processing by the opioid system in the brain. Physiol. Rev. 89, 1379-1412. doi: 10.1152/physrev.00005.2009

Lemos, J. C., Roth, C. A., Messinger, D. I., Gill, H. K., Phillips, P. E., and Chavkin, C. (2012). Repeated stress dysregulates kappa-opioid receptor signaling in the dorsal raphe through a p38alpha MAPK-dependent mechanism. J. Neurosci. 32, 12325-12336. doi: 10.1523/JNEUROSCI.2053-12.2012

Li, J. L., Ding, Y. Q., Li, Y. Q., Li, J. S., Nomura, S., Kaneko, T., et al. (1998) Immunocytochemical localization of mu-opioid receptor in primary afferent neurons containing substance $\mathrm{P}$ or calcitonin gene-related peptide. A light and electron microscope study in the rat. Brain Res. 794, 347-352. doi: 10.1016/S0006-8993(98)00332-1

Liao, Y. J., Jan, Y. N., and Jan, L. Y. (1996). Heteromultimerization of G-proteingated inwardly rectifying $\mathrm{K}^{+}$channel proteins GIRK1 and GIRK2 and their altered expression in weaver brain. J. Neurosci. 16, 7137-7150.

Lober, R. M., Pereira, M. A., and Lambert, N. A. (2006). Rapid activation of inwardly rectifying potassium channels by immobile G-protein-coupled receptors. J. Neurosci. 26, 12602-12608. doi: 10.1523/JNEUROSCI.402006.2006

Logothetis, D. E., Kurachi, Y., Galper, J., Neer, E. J., and Clapham, D. E. (1987). The beta gamma subunits of GTP-binding proteins activate the muscarinic $\mathrm{K}^{+}$ channel in heart. Nature 325, 321-326. doi: 10.1038/325321a0

Lohse, M. J., Nuber, S., and Hoffmann, C. (2012). Fluorescence/bioluminescence resonance energy transfer techniques to study G-protein-coupled receptor activation and signaling. Pharmacol. Rev. 64, 299-336. doi: 10.1124/pr.110.004309

Lotsch, J., Pruss, H., Veh, R. W., and Doehring, A. (2010). A KCNJ6 (Kir3.2, GIRK2) gene polymorphism modulates opioid effects on analgesia and addiction but not on pupil size. Pharmacogenet. Genomics 20, 291-297. doi: 10.1097/FPC.0b013e3283386bda

Lujan, R., Marron Fernandez De Velasco, E., Aguado, C., and Wickman, K. (2014). New insights into the therapeutic potential of Girk channels. Trends Neurosci. 37, 20-29. doi: 10.1016/j.tins.2013.10.006

Luscher, C., Jan, L. Y., Stoffel, M., Malenka, R. C., and Nicoll, R. A. (1997). G protein-coupled inwardly rectifying $\mathrm{K}^{+}$channels (GIRKs) mediate postsynaptic but not presynaptic transmitter actions in hippocampal neurons. Neuron 19, 687-695. doi: 10.1016/S0896-6273(00)80381-5

Luscher, C., and Slesinger, P. A. (2010). Emerging roles for G protein-gated inwardly rectifying potassium (GIRK) channels in health and disease. Nat. Rev. Neurosci. 11, 301-315. doi: 10.1038/nrn2834

Luscher, C., and Ungless, M. A. (2006). The mechanistic classification of addictive drugs. PLoS Med. 3:e437. doi: 10.1371/journal.pmed.0030437

Marker, C. L., Cintora, S. C., Roman, M. I., Stoffel, M., and Wickman, K. (2002). Hyperalgesia and blunted morphine analgesia in G protein-gated potassium channel subunit knockout mice. Neuroreport 13, 2509-2513. doi: 10.1097/00001756-200212200-00026

Marker, C. L., Lujan, R., Colon, J., and Wickman, K. (2006). Distinct populations of spinal cord lamina II interneurons expressing G-protein-gated potassium channels. J. Neurosci. 26, 12251-12259. doi: 10.1523/JNEUROSCI.369306.2006

Marker, C. L., Lujan, R., Loh, H. H., and Wickman, K. (2005). Spinal G-proteingated potassium channels contribute in a dose-dependent manner to the analgesic effect of mu- and delta- but not kappa-opioids. J. Neurosci. 25, 3551-3559. doi: 10.1523/JNEUROSCI.4899-04.2005

Marker, C. L., Stoffel, M., and Wickman, K. (2004). Spinal G-protein-gated K ${ }^{+}$ channels formed by GIRK1 and GIRK2 subunits modulate thermal nociception and contribute to morphine analgesia. J. Neurosci. 24, 2806-2812. doi: 10.1523/JNEUROSCI.5251-03.2004

Mase, Y., Yokogawa, M., Osawa, M., and Shimada, I. (2012). Structural basis for modulation of gating property of $\mathrm{G}$ protein-gated inwardly rectifying potassium 
ion channel (GIRK) by i/o-family G protein alpha subunit (Galphai/o). J. Biol. Chem. 287, 19537-19549. doi: 10.1074/jbc.M112.353888

McAllister, S. D., Griffin, G., Satin, L. S., and Abood, M. E. (1999). Cannabinoid receptors can activate and inhibit $\mathrm{G}$ protein-coupled inwardly rectifying potassium channels in a xenopus oocyte expression system. J. Pharmacol. Exp. Ther. 291, 618-626.

McLaughlin, J. P., Myers, L. C., Zarek, P. E., Caron, M. G., Lefkowitz, R. J., Czyzyk, T. A., et al. (2004). Prolonged kappa opioid receptor phosphorylation mediated by G-protein receptor kinase underlies sustained analgesic tolerance. J. Biol. Chem. 279, 1810-1818. doi: 10.1074/jbc.M305796200

Mitrovic, I., Margeta-Mitrovic, M., Bader, S., Stoffel, M., Jan, L. Y., and Basbaum, A. I. (2003). Contribution of GIRK2-mediated postsynaptic signaling to opiate and alpha 2-adrenergic analgesia and analgesic sex differences. Proc. Natl. Acad. Sci. U.S.A. 100, 271-276. doi: 10.1073/pnas. 0136822100

Mogil, J. S. (2009). Are we getting anywhere in human pain genetics? Pain 146, 231-232. doi: 10.1016/j.pain.2009.07.023

Moore, S. D., Madamba, S. G., Schweitzer, P., and Siggins, G. R. (1994). Voltagedependent effects of opioid peptides on hippocampal CA3 pyramidal neurons in vitro. J. Neurosci. 14, 809-820.

Morgan, M. M., and Christie, M. J. (2011). Analysis of opioid efficacy, tolerance, addiction and dependence from cell culture to human. Br. J. Pharmacol. 164, 1322-1334. doi: 10.1111/j.1476-5381.2011.01335.x

Nassirpour, R., Bahima, L., Lalive, A. L., Luscher, C., Lujan, R., and Slesinger, P. A. (2010). Morphine- and CaMKII-dependent enhancement of GIRK channel signaling in hippocampal neurons. J. Neurosci. 30, 13419-13430. doi: 10.1523/JNEUROSCI.2966-10.2010

Navarro, B., Kennedy, M. E., Velimirovic, B., Bhat, D., Peterson, A. S., and Clapham, D. E. (1996). Nonselective and $\mathrm{G}$ betagamma-insensitive weaver $\mathrm{K}^{+}$channels. Science 272, 1950-1953. doi: 10.1126/science.272.5270.1950

Neer, E. J. (1995). Heterotrimeric $G$ proteins: organizers of transmembrane signals. Cell 80, 249-257. doi: 10.1016/0092-8674(95)90407-7

Neubig, R. R. (1994). Membrane organization in G-protein mechanisms. FASEB J. 8, 939-946.

Nishizawa, D., Nagashima, M., Katoh, R., Satoh, Y., Tagami, M., Kasai, S., et al. (2009). Association between KCNJ6 (GIRK2) gene polymorphisms and postoperative analgesic requirements after major abdominal surgery. PLOS ONE 4:e7060. doi: 10.1371/journal.pone.0007060

Nobles, M., Benians, A., and Tinker, A. (2005). Heterotrimeric G proteins precouple with $\mathrm{G}$ protein-coupled receptors in living cells. Proc. Natl. Acad. Sci. U.S.A. 102, 18706-18711. doi: 10.1073/pnas.0504778102

Nockemann, D., Rouault, M., Labuz, D., Hublitz, P., McKnelly, K., Reis, F. C., et al. (2013). The $\mathrm{K}(+)$ channel GIRK2 is both necessary and sufficient for peripheral opioid-mediated analgesia. EMBO Mol. Med. 5, 1263-1277. doi: 10.1002/emmm.201201980

Obara, I., Parkitna, J. R., Korostynski, M., Makuch, W., Kaminska, D., Przewlocka, B., et al. (2009). Local peripheral opioid effects and expression of opioid genes in the spinal cord and dorsal root ganglia in neuropathic and inflammatory pain. Pain 141, 283-291. doi: 10.1016/j.pain.2008.12.006

Orly, J., and Schramm, M. (1976). Coupling of catecholamine receptor from one cell with adenylate cyclase from another cell by cell fusion. Proc. Natl. Acad. Sci. U.S.A. 73, 4410-4414. doi: 10.1073/pnas.73.12.4410

Padgett, C. L., Lalive, A. L., Tan, K. R., Terunuma, M., Munoz, M. B., Pangalos, M. N., et al. (2012). Methamphetamine-evoked depression of GABA(B) receptor signaling in GABA neurons of the VTA. Neuron 73, 978-989. doi: 10.1016/j.neuron.2011.12.031

Patil, N., Cox, D. R., Bhat, D., Faham, M., Myers, R. M., and Peterson, A. S. (1995). A potassium channel mutation in weaver mice implicates membrane excitability in granule cell differentiation. Nat. Genet. 11, 126-129. doi: 10.1038/ ng1095-126

Pert, C. B., and Snyder, S. H. (1973). Opiate receptor: demonstration in nervous tissue. Science 179, 1011-1014. doi: 10.1126/science.179.4077.1011

Pradhan, A. A., Befort, K., Nozaki, C., Gaveriaux-Ruff, C., and Kieffer, B. L. (2011). The delta opioid receptor: an evolving target for the treatment of brain disorders. Trends Pharmacol. Sci. 32, 581-590. doi: 10.1016/j.tips.2011.06.008

Pradhan, A. A., Walwyn, W., Nozaki, C., Filliol, D., Erbs, E., Matifas, A., et al. (2010). Ligand-directed trafficking of the delta-opioid receptor in vivo: two paths toward analgesic tolerance. J. Neurosci. 30, 16459-16468. doi: 10.1523/JNEUROSCI.3748-10.2010
Pravetoni, M., and Wickman, K. (2008). Behavioral characterization of mice lacking GIRK/Kir3 channel subunits. Genes Brain Behav. 7, 523-531. doi: 10.1111/j.1601-183X.2008.00388.x

Raehal, K. M., Walker, J. K., and Bohn, L. M. (2005). Morphine side effects in beta-arrestin 2 knockout mice. J. Pharmacol. Exp. Ther. 314, 1195-1201. doi: 10.1124/jpet.105.087254

Rasmussen, S. G., Devree, B. T., Zou, Y., Kruse, A. C., Chung, K. Y., Kobilka, T. S., et al. (2011). Crystal structure of the beta2 adrenergic receptor-Gs protein complex. Nature 477, 549-555. doi: 10.1038/nature10361

Raveh, A., Riven, I., and Reuveny, E. (2009). Elucidation of the gating of the GIRK channel using a spectroscopic approach. J. Physiol. 587, 5331-5335. doi: 10.1113/jphysiol.2009.180158

Rebois, R. V., Robitaille, M., Gales, C., Dupre, D. J., Baragli, A., Trieu, P., et al. (2006). Heterotrimeric $G$ proteins form stable complexes with adenylyl cyclase and Kir3.1 channels in living cells. J. Cell Sci. 119, 2807-2818. doi: $10.1242 /$ jcs.03021

Richard-Lalonde, M., Nagi, K., Audet, N., Sleno, R., Amraei, M., Hogue, M., et al. (2013). Conformational dynamics of Kir3.1/Kir3.2 channel activation via deltaopioid receptors. Mol. Pharmacol. 83, 416-428. doi: 10.1124/mol.112.081950

Riven, I., Iwanir, S., and Reuveny, E. (2006). GIRK channel activation involves a local rearrangement of a preformed G protein channel complex. Neuron 51, 561-573. doi: 10.1016/j.neuron.2006.08.017

Robitaille, M., Ramakrishnan, N., Baragli, A., and Hebert, T. E. (2009). Intracellular trafficking and assembly of specific Kir3 channel/G protein complexes. Cell. Signal. 21, 488-501. doi: 10.1016/j.cellsig.2008.11.011

Romero, G., Von Zastrow, M., and Friedman, P. A. (2011). Role of PDZ proteins in regulating trafficking, signaling, and function of GPCRs: means, motif, and opportunity. Adv. Pharmacol. 62, 279-314. doi: 10.1016/B978-0-12-3859525.00003-8

Rusinova, R., Mirshahi, T., and Logothetis, D. E. (2007). Specificity of Gbetagamma signaling to Kir3 channels depends on the helical domain of pertussis toxin-sensitive Galpha subunits. J. Biol. Chem. 282, 34019-34030. doi: 10.1074/jbc.M704928200

Saenz Del Burgo, L., Cortes, R., Mengod, G., Zarate, J., Echevarria, E., and Salles, J. (2008). Distribution and neurochemical characterization of neurons expressing GIRK channels in the rat brain. J. Comp. Neurol. 510, 581-606. doi: $10.1002 / \mathrm{cne} .21810$

Saitoh, A., Sugiyama, A., Nemoto, T., Fujii, H., Wada, K., Oka, J., et al. (2011). The novel delta opioid receptor agonist KNT-127 produces antidepressant-like and antinociceptive effects in mice without producing convulsions. Behav. Brain Res. 223, 271-279. doi: 10.1016/j.bbr.2011.04.041

Scherrer, G., Imamachi, N., Cao, Y. Q., Contet, C., Mennicken, F., O’Donnell, D., et al. (2009). Dissociation of the opioid receptor mechanisms that control mechanical and heat pain. Cell 137, 1148-1159. doi: 10.1016/j.cell.2009. 04.019

Schreibmayer, W., Dessauer, C. W., Vorobiov, D., Gilman, A. G., Lester, H. A., Davidson, N., et al. (1996). Inhibition of an inwardly rectifying $\mathrm{K}^{+}$channel by G-protein alpha-subunits. Nature 380, 624-627. doi: 10.1038/380624a0

Signorini, S., Liao, Y. J., Duncan, S. A., Jan, L. Y., and Stoffel, M. (1997). Normal cerebellar development but susceptibility to seizures in mice lacking $\mathrm{G}$ proteincoupled, inwardly rectifying $\mathrm{K}^{+}$channel GIRK2. Proc. Natl. Acad. Sci. U.S.A. 94, 923-927. doi: 10.1073/pnas.94.3.923

Simon, E. J., Hiller, J. M., and Edelman, I. (1973). Stereospecific binding of the potent narcotic analgesic $(3 \mathrm{H})$ Etorphine to rat-brain homogenate. Proc. Natl. Acad. Sci. U.S.A. 70, 1947-1949. doi: 10.1073/pnas.70.7.1947

Stein, C., Millan, M. J., Shippenberg, T. S., Peter, K., and Herz, A. (1989). Peripheral opioid receptors mediating antinociception in inflammation. Evidence for involvement of mu, delta and kappa receptors. J. Pharmacol. Exp. Ther. 248, 1269-1275.

Tavani, A., Petrillo, P., La Regina, A., and Sbacchi, M. (1990). Role of peripheral mu, delta and kappa opioid receptors in opioid-induced inhibition of gastrointestinal transit in rats. J. Pharmacol. Exp. Ther. 254, 91-97.

Tian, W. N., Duzic, E., Lanier, S. M., and Deth, R. C. (1994). Determinants of alpha 2-adrenergic receptor activation of $G$ proteins: evidence for a precoupled receptor/G protein state. Mol. Pharmacol. 45, 524-531.

Tolkovsky, A. M., and Levitzki, A. (1978). Mode of coupling between the betaadrenergic receptor and adenylate cyclase in turkey erythrocytes. Biochemistry 17, 3795. doi: 10.1021/bi00611a020 
Urban, J. D., Clarke, W. P., Von Zastrow, M., Nichols, D. E., Kobilka, B., Weinstein, H., et al. (2007). Functional selectivity and classical concepts of quantitative pharmacology. J. Pharmacol. Exp. Ther. 320, 1-13. doi: 10.1124/jpet.106.104463

Vadivelu, N., Mitra, S., and Hines, R. L. (2011). Peripheral opioid receptor agonists for analgesia: a comprehensive review. J. Opioid Manag. 7, 55-68. doi: 10.5055/jom.2011.0049

Van't Veer, A., and Carlezon, W. A. Jr. (2013). Role of kappa-opioid receptors in stress and anxiety-related behavior. Psychopharmacology (Berl.) 229, 435-452. doi: 10.1007/s00213-013-3195-5

Vaughan, C. W., and Christie, M. J. (1997). Presynaptic inhibitory action of opioids on synaptic transmission in the rat periaqueductal grey in vitro. J. Physiol. 498(Pt 2), 463-472.

Vaughan, C. W., Ingram, S. L., Connor, M. A., and Christie, M. J. (1997). How opioids inhibit GABA-mediated neurotransmission. Nature 390, 611-614. doi: $10.1038 / 37610$

Vilardaga, J. P., Bunemann, M., Krasel, C., Castro, M., and Lohse, M. J. (2003). Measurement of the millisecond activation switch of $\mathrm{G}$ protein-coupled receptors in living cells. Nat. Biotechnol. 21, 807-812. doi: 10.1038/nbt838

Waldhoer, M., Fong, J., Jones, R. M., Lunzer, M. M., Sharma, S. K., Kostenis, E., et al. (2005). A heterodimer-selective agonist shows in vivo relevance of $\mathrm{G}$ protein-coupled receptor dimers. Proc. Natl. Acad. Sci. U.S.A. 102, 9050-9055. doi: 10.1073/pnas.0501112102

Wang, H. B., Zhao, B., Zhong, Y. Q., Li, K. C., Li, Z. Y., Wang, Q., et al. (2010). Coexpression of delta- and mu-opioid receptors in nociceptive sensory neurons. Proc. Natl. Acad. Sci. U.S.A. 107, 13117-13122. doi: 10.1073/pnas.1008382107

Wei, Z. Y., Karim, F., and Roerig, S. C. (1996). Spinal morphine/clonidine antinociceptive synergism: involvement of $\mathrm{G}$ proteins and $\mathrm{N}$-type voltage-dependent calcium channels. J. Pharmacol. Exp. Ther. 278, 1392-1407.

Whorton, M. R., and MacKinnon, R. (2011). Crystal structure of the mammalian GIRK2 $\mathrm{K}^{+}$channel and gating regulation by $\mathrm{G}$ proteins, PIP2, and sodium. Cell 147, 199-208. doi: 10.1016/j.cell.2011.07.046

Whorton, M. R., and MacKinnon, R. (2013). X-ray structure of the mammalian GIRK2-betagamma G-protein complex. Nature 498, 190-197. doi: 10.1038 /nature 12241

Wickman, K., Karschin, C., Karschin, A., Picciotto, M. R., and Clapham, D. E. (2000). Brain localization and behavioral impact of the G-protein-gated $\mathrm{K}^{+}$ channel subunit GIRK4. J. Neurosci. 20, 5608-5615.

Wickman, K., Nemec, J., Gendler, S. J., and Clapham, D. E. (1998). Abnormal heart rate regulation in GIRK4 knockout mice. Neuron 20, 103-114. doi: 10.1016/S0896-6273(00)80438-9

Wickman, K. D., Iniguez-Lluhl, J. A., Davenport, P. A., Taussig, R., Krapivinsky, G. B., Linder, M. E., et al. (1994). Recombinant G-protein beta gamma-subunits activate the muscarinic-gated atrial potassium channel. Nature 368, 255-257. doi: $10.1038 / 368255 \mathrm{a} 0$

Wimpey, T. L., and Chavkin, C. (1991). Opioids activate both an inward rectifier and a novel voltage-gated potassium conductance in the hippocampal formation. Neuron 6, 281-289. doi: 10.1016/0896-6273(91) 90363-5

Wreggett, K. A., and De Lean, A. (1984). The ternary complex model. Its properties and application to ligand interactions with the D2-dopamine receptor of the anterior pituitary gland. Mol. Pharmacol. 26, 214-227.

Wrigley, P. J., Jeong, H. J., and Vaughan, C. W. (2010). Dissociation of mu- and delta-opioid inhibition of glutamatergic synaptic transmission in superficial dorsal horn. Mol. Pain 6:71. doi: 10.1186/1744-8069-6-71

Wu, Z. Z., Chen, S. R., and Pan, H. L. (2008). Distinct inhibition of voltageactivated $\mathrm{Ca}^{2+}$ channels by delta-opioid agonists in dorsal root ganglion neurons devoid of functional T-type $\mathrm{Ca}^{2+}$ currents. Neuroscience 153, 1256-1267. doi: 10.1016/j.neuroscience.2008.03.031

Xu, M., Petraschka, M., McLaughlin, J. P., Westenbroek, R. E., Caron, M. G., Lefkowitz, R. J., et al. (2004). Neuropathic pain activates the endogenous kappa opioid system in mouse spinal cord and induces opioid receptor tolerance. J. Neurosci. 24, 4576-4584. doi: 10.1523/JNEUROSCI.5552-03.2004

Yang, H. Y., Wu, Z. Y., Wood, M., Whiteman, M., and Bian, J. S. (2014). Hydrogen sulfide attenuates opioid dependence by suppression of adenylate cyclase/cAMP pathway. Antioxid. Redox Signal. 20, 31-41. doi: 10.1089/ars.2012.5119

Yokogawa, M., Osawa, M., Takeuchi, K., Mase, Y., and Shimada, I. (2011). NMR analyses of the Gbetagamma binding and conformational rearrangements of the cytoplasmic pore of $\mathrm{G}$ protein-activated inwardly rectifying potassium channel 1 (GIRK1). J. Biol. Chem. 286, 2215-2223. doi: 10.1074/jbc.M110.160754

Conflict of Interest Statement: The authors declare that the research was conducted in the absence of any commercial or financial relationships that could be construed as a potential conflict of interest.

Received: 16 March 2014; accepted: 18 June 2014; published online: 08 July 2014. Citation: Nagi K and Pineyro G (2014) Kir3 channel signaling complexes: focus on opioid receptor signaling. Front. Cell. Neurosci. 8:186. doi: 10.3389/fncel.2014.00186 This article was submitted to the journal Frontiers in Cellular Neuroscience.

Copyright (c) 2014 Nagi and Pineyro. This is an open-access article distributed under the terms of the Creative Commons Attribution License (CC BY). The use, distribution or reproduction in other forums is permitted, provided the original author(s) or licensor are credited and that the original publication in this journal is cited, in accordance with accepted academic practice. No use, distribution or reproduction is permitted which does not comply with these terms. 